\title{
القابلية للإساءة الزوجية وعلاقتها بالتوافق المهني لدي المعلمات في ضوء بعض المتغيرات الديموجرافية
}

\author{
إعداد \\ أ/ جهاد وحيد محمد \\ باحثة ماجستير \\ بقسم علم النفس التربوي والصحة النفسية \\ كلية التربية جامعة دمياط.

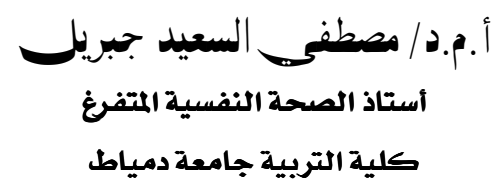 \\ كلية التربية جامعة دمياط
}

مجلة بحوث التربية النوعية ـ جامعة المنصورة

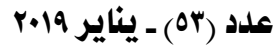




\title{
القابلية للإساءة الززوجية وعلاقتها بالتوافق المهني لدي المعلمات في ضوى بعض المتغيرات الديموجرافية
}

\author{
| (إعداد \\ "**/ جهاد وحيد محمد \\ أ. . .د / مصطف السعبد جبريل
}

: الإنصט

هدف البحث الحالي إلي إلقاء الضوء علي القابلية للإساءة الزوجية وعلاقتها بالتوافق المهني لدي

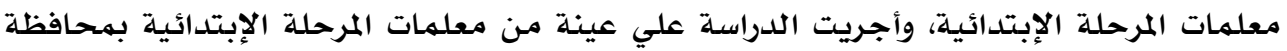

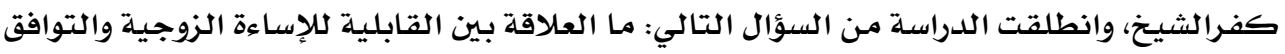

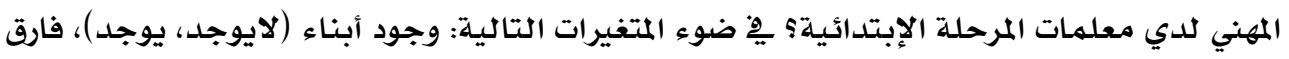

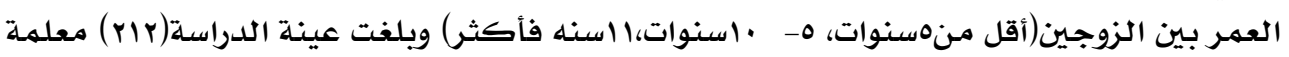

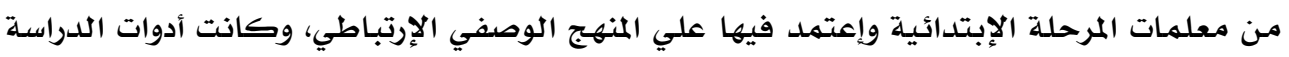

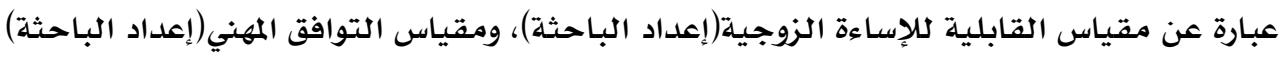

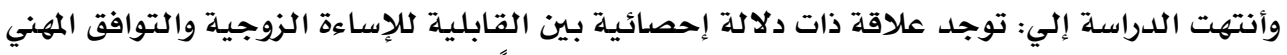

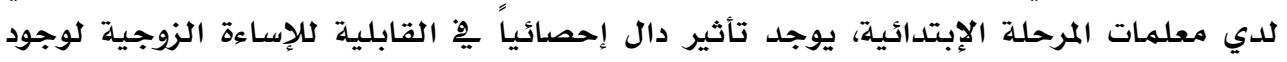

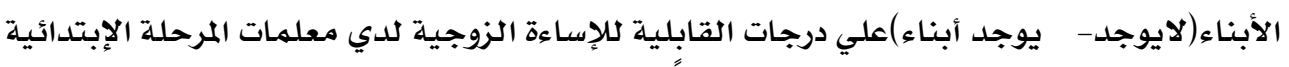

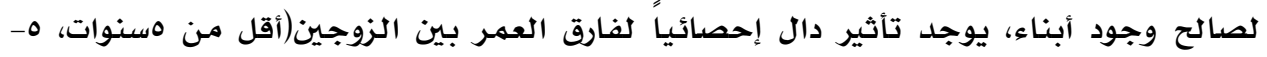

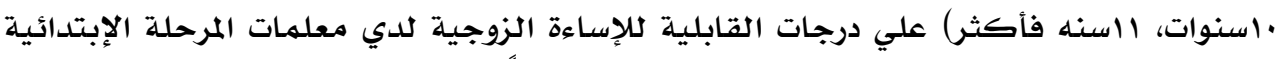

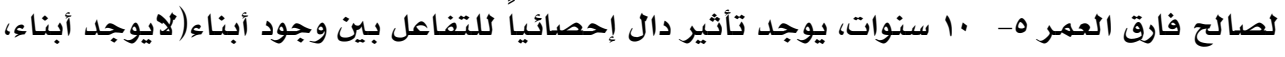

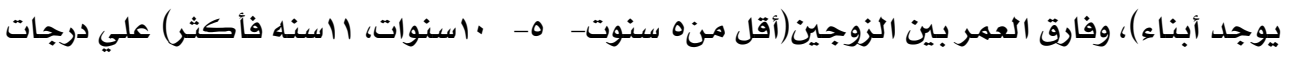

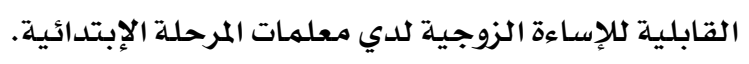

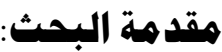

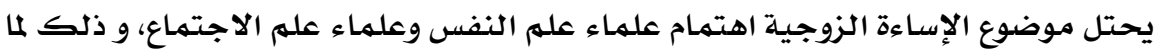

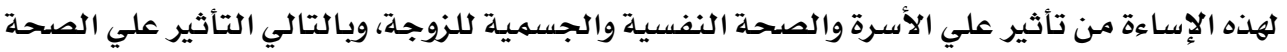

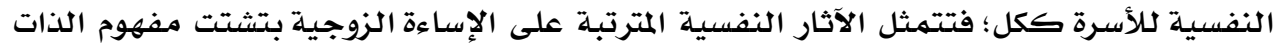

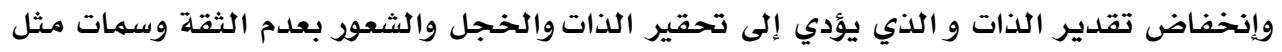

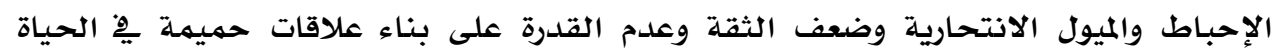


بالإضافة إلى التشتت وعدم وضوح الأهداف، وهذا ينعكس بآثاره علي التوافق المهني للزوجة(أسماء

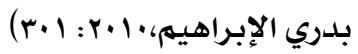

ويشير الباحثون ِِْ هذا الصدد إلي أن الفرد الذي يتعرض لضغوط أسرية مثلا قد يكون

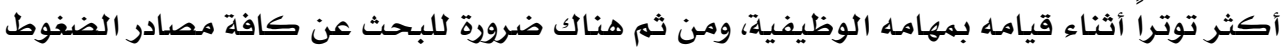

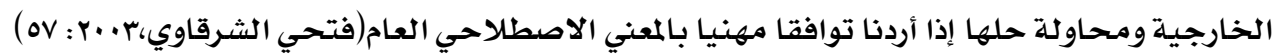

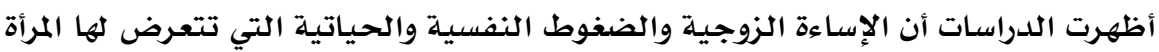

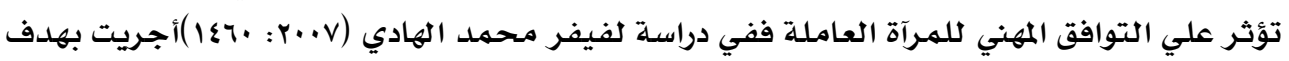

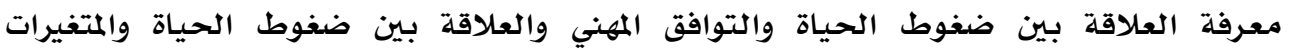

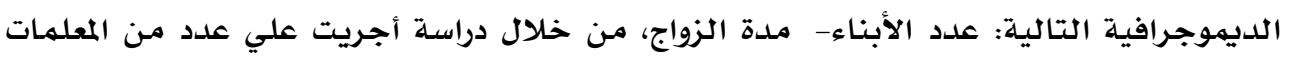

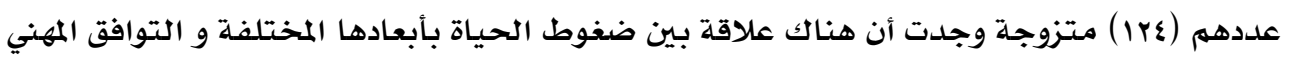

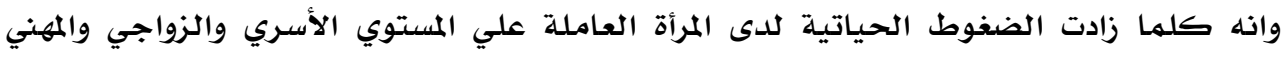

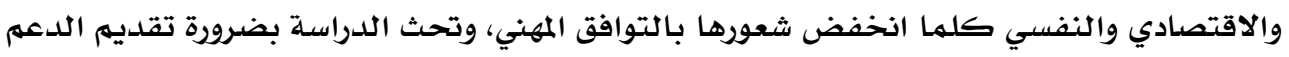

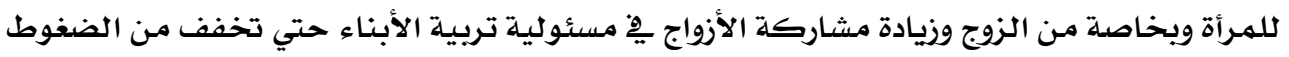

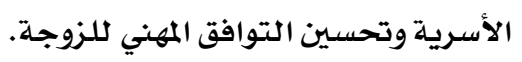

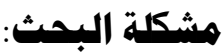

تتمثل مشكلة البحث الحالي يِّ الوقوف علي الأسباب التي تجعل الزوجة متقبلة للإساءة

الزوجية من قبل شريك حياتها رغم ما تسببـه هذه الإساءة من آثار نفسية وتتأثر حياتها بكل

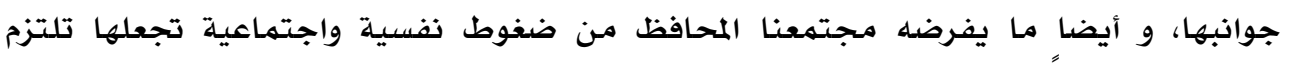

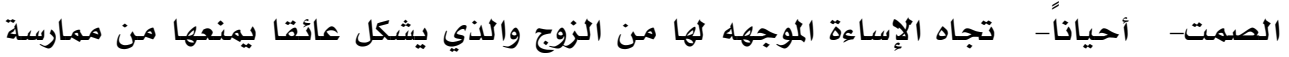

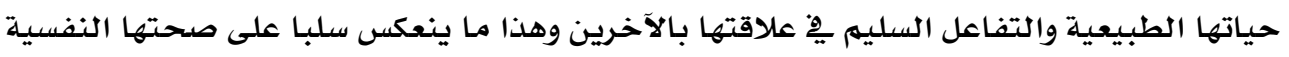
وصحتها العامـةوتوافقها المهني.

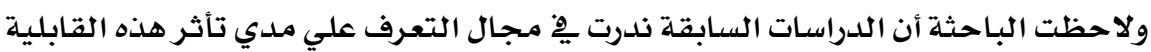

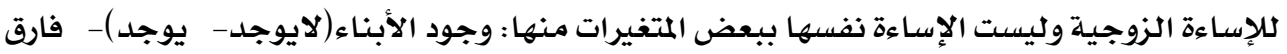
العمبر بين الزوجين.

ومما سبق تتبلور مشكلة البحث يِ تعرض المرأة لأشكال مختلف من الإساءة الزوجية

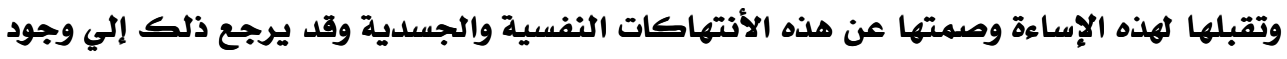

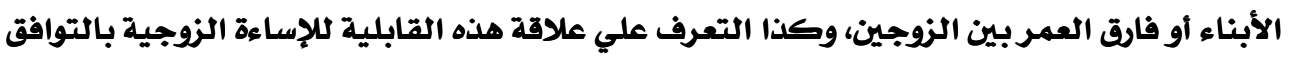

المهني للزوجة.

\section{ويمكن صياغة مشكلة البحث الحالية يِّ التساؤلات الآتية:}

ا. هل توجد علاقة ذات دلادة إحصائية بين القابلية للإساءة الزوجية والتوافق المهني لدي

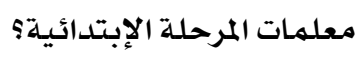




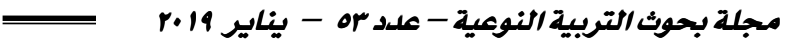

r. هل يوجد تأثير دال إحصائياً لوجود أبناء(لايوجد أبناء- يوجد أبناء)علي درجات القابلية

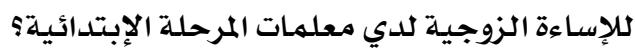

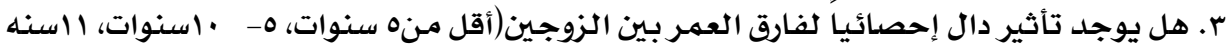

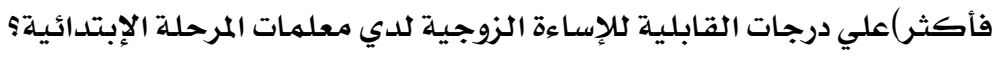

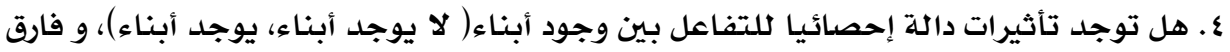

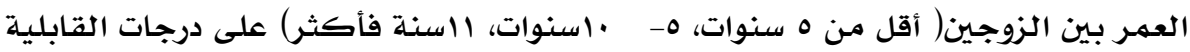

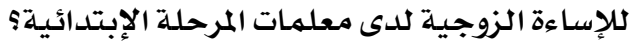

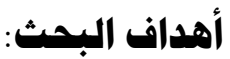

ا ـ التعرف علي العلاقة بين القابلية للإساءة الزوجية والتوافق المهني لدي المعلمات المتزوجات مـن معلمات المرحلة الإبتدائية. r. الكثف عن مدي تأثر القابلية للإسـاءة الزوجية بأختلاف وجود أبناء(لايوجد أبناء- يوجد أبناء) لدي معلمات المرحلة الإبتدائية.

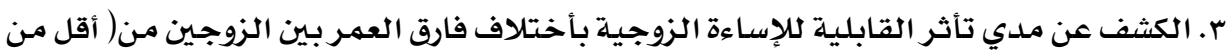

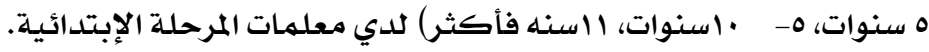

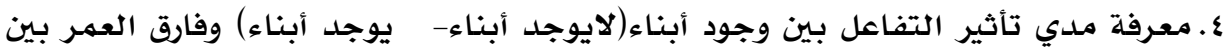

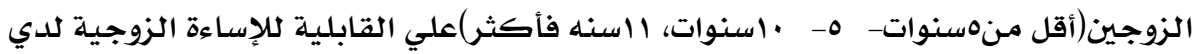
معلمات المرحلة الإبتدائية.

تتمثل أهمية البحث ِِّ أنه يلقي الضوء علي موضوعاً يهم المرأة والمجتمع ككل، وهو

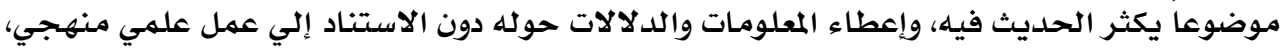

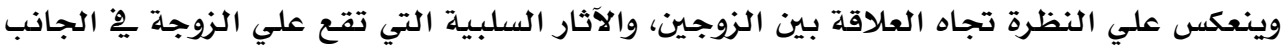

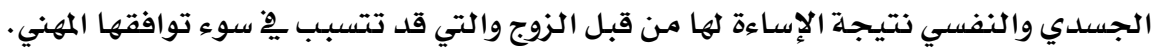
إطار نظري:

\section{أولاً: القابلية للإساءة الزوجية:}

المرأة المصرية صاحبة تاريخ طويل ممتد عبر سبعة آلاف عام، كانت فيها شريكة للرجل فِيْ كل إنجازات حضارتنا، وريما لم تشهد حضارة من الحضارات القديمة مكانة متميزة للمرأة مثلما

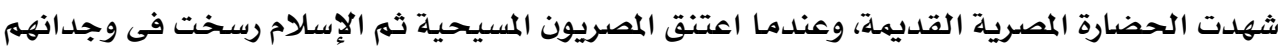

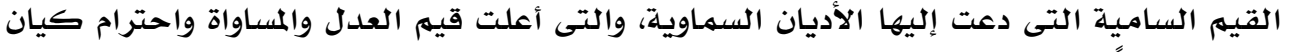

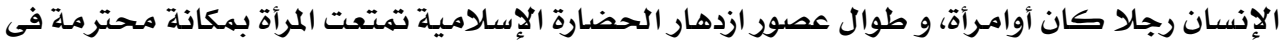

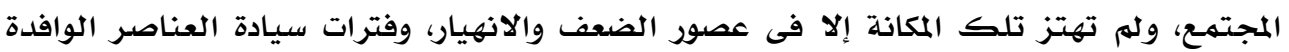


الأجنبية بها تحمله من تصورات وأفكار مغايرة لميراثنا الحضارى الذى يجل المرأة ويحترمها(هدي

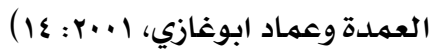

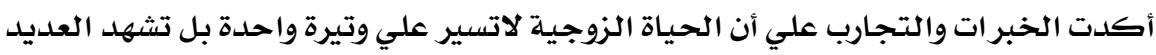

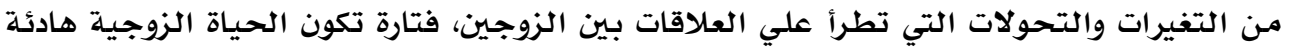

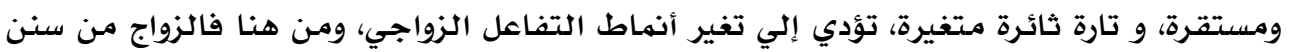

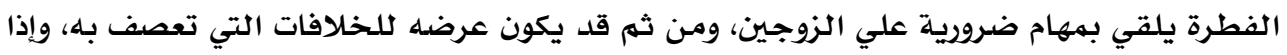

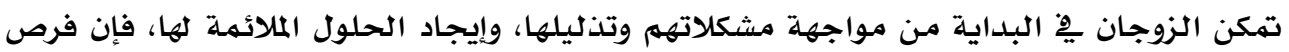

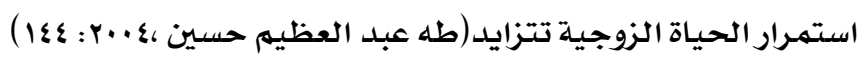

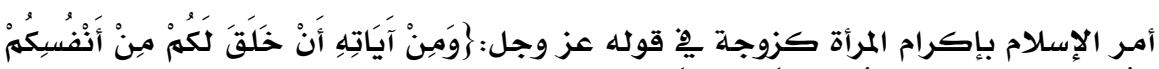

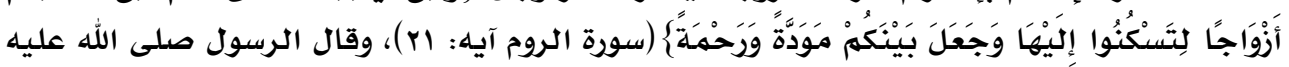

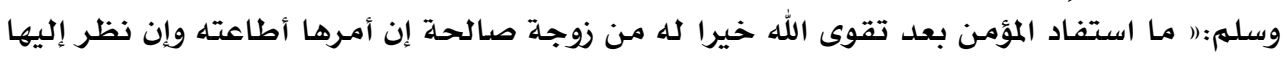

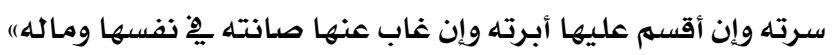
: Marital Abuse الإساءة الزوجية

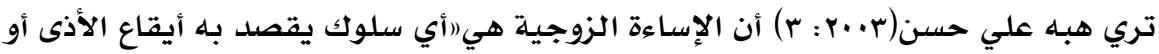

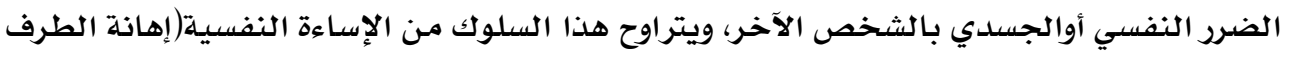

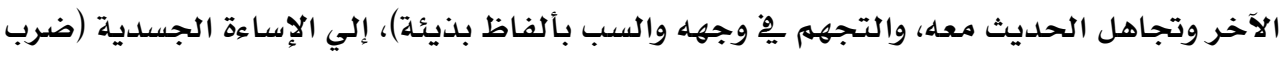

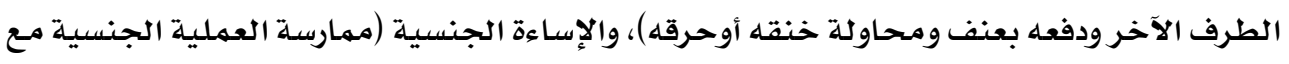

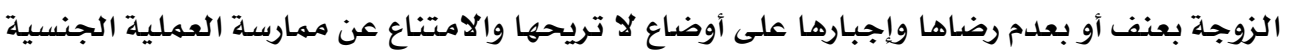

معها)

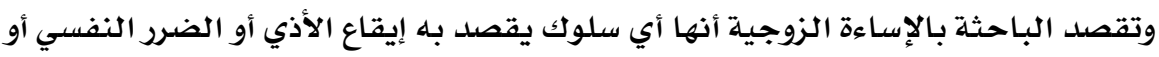

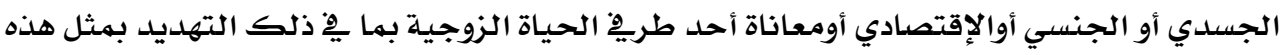

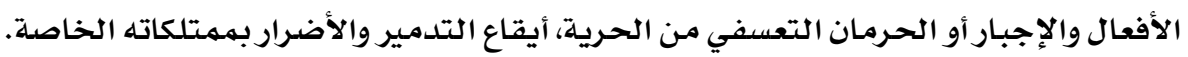

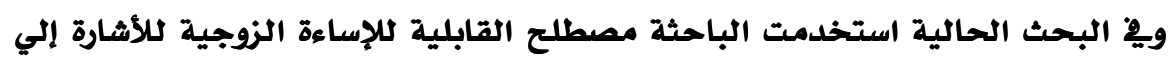

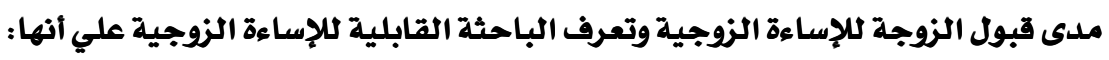

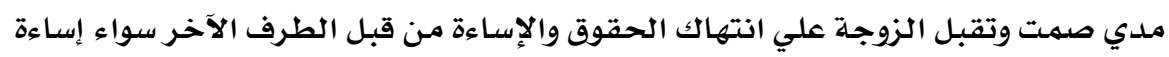

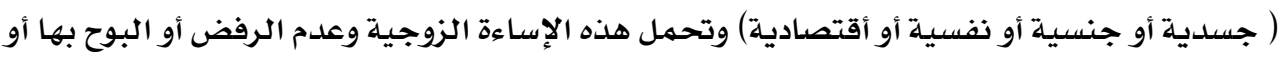

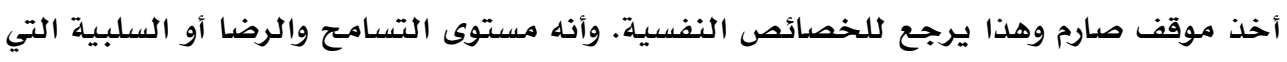

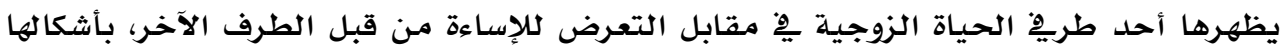

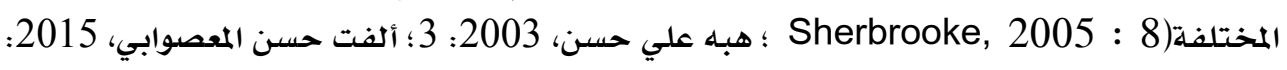


أشكال الإساءة الزوجية:

| الإساءة الجسدية :

تعرف علي أنها إسـاءة موجهة لجسهم الزوجة واستخدام القوة يُّْ إلحاق الأذى الجسدي مثل

الضرب والركل والقذف والصفع والحرق وحرمانها من تلقي الرعاية الصحية.

وتظهر - والآتي:

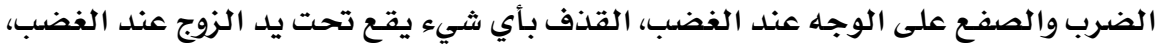

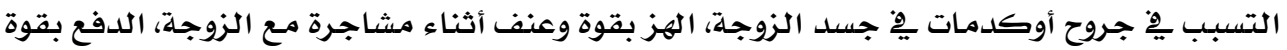

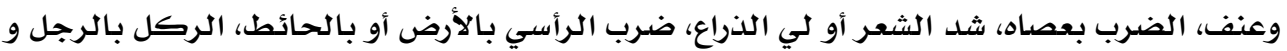

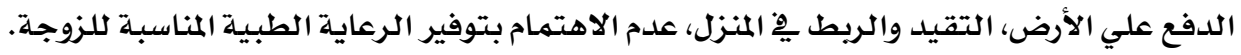

: ب الإساءة النفسية

تعرف على أنها أي فعل يتسبب يِّ إلحاق ضرر معنوي وحسي وتلحق الضرر النفسي

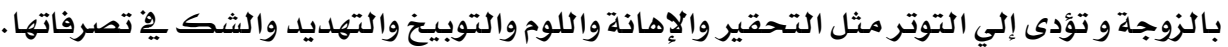

\section{وتظهر فِ الآتي:}

التهديد بالطلاق، الحرمان من رعاية أبناء، التدخل يِّ علاقات مـع الأهل والمعارف، إعتبار

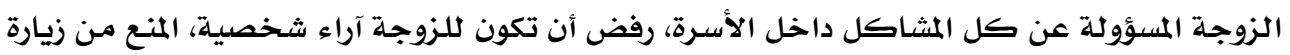

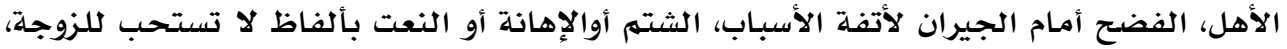

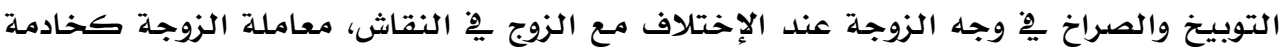

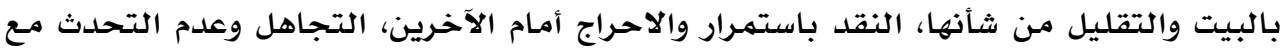
الزوجة ِِ أنى مشكلة.

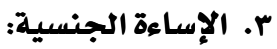

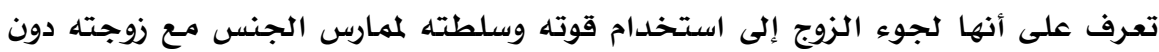

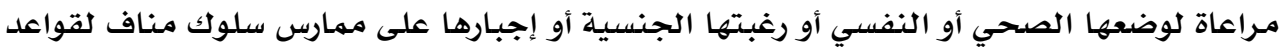

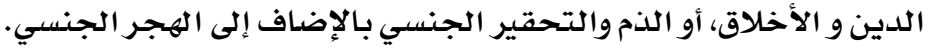

\section{وتظهر - و الآتي:}

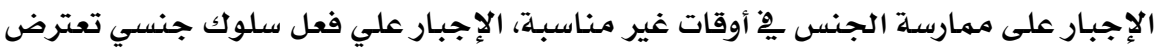

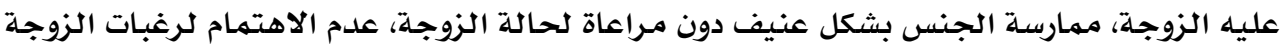

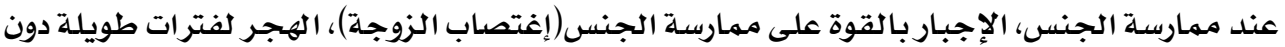


تعرف على أنها: "الحرمان من الأنفاق أوالمصروف، أوالابتزاز المادي، أوعدم تحمل المسؤولية

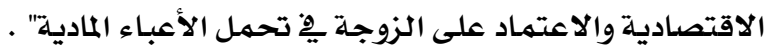

\section{وتظهر بِ الآتي:}

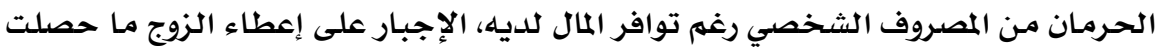

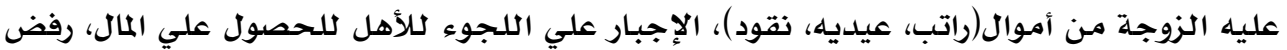

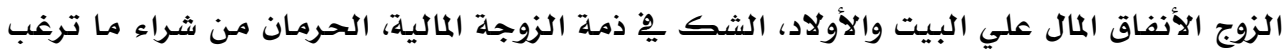

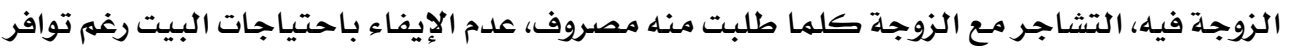

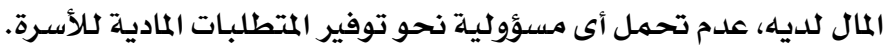

أسباب القابلية للإساءة الزوجية: أ أ. أسباب خاصة بالزوجة المتقبلة للإسعاءة:

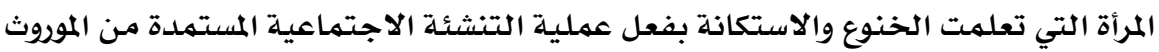

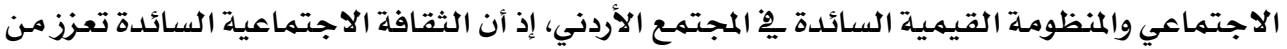

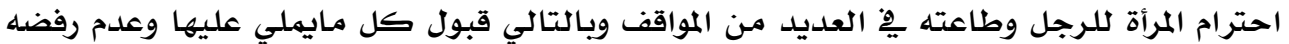

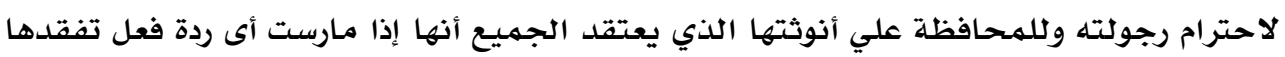

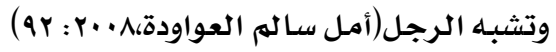

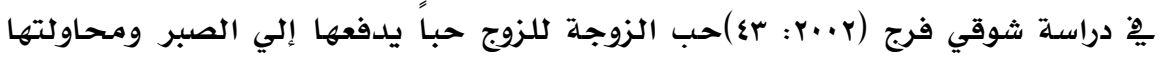

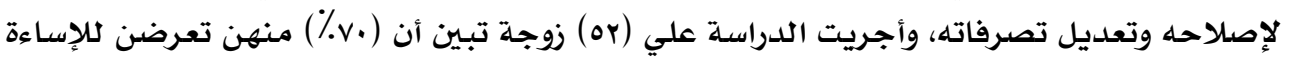

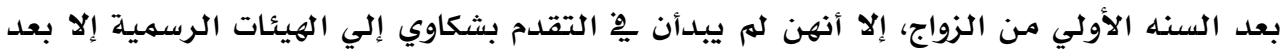

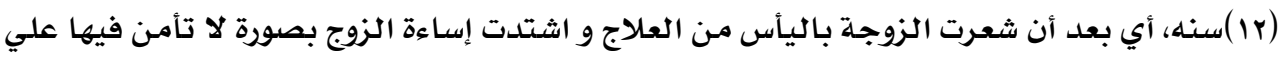

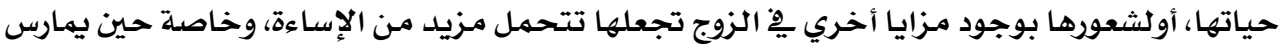

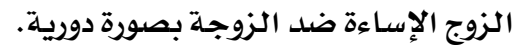$$
\text { ب. أسباب خاصة بالزوج المسئ لزوجته: }
$$

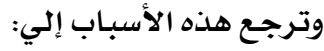

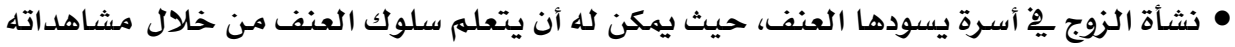

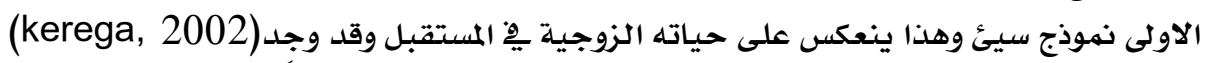

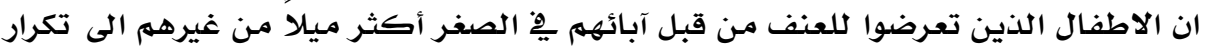

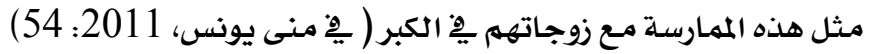

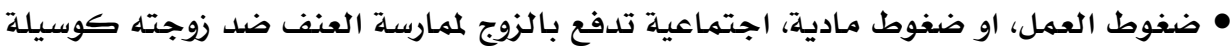

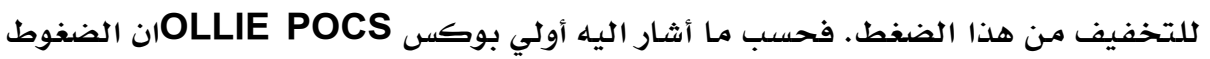

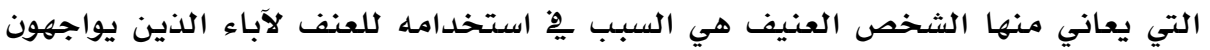


مشاكل كالبطالة والخلافات الزوجية يكونون أكثر ميلاً للعنف مـع أطفا لهم وزوجاتهم (منال عباس، مباسكال 2011: 103 )

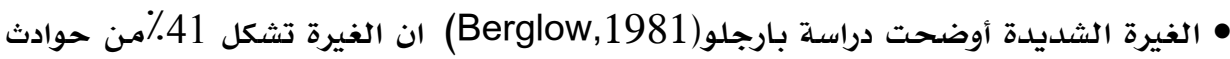

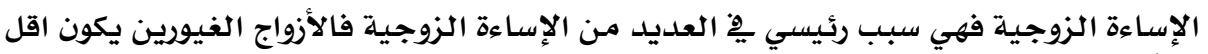

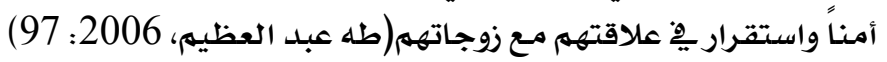
وقد أمكن للباحثة الوقوف علي بعض الأسباب التي قد تدفع الزوج لممارسة الإساءة ضد

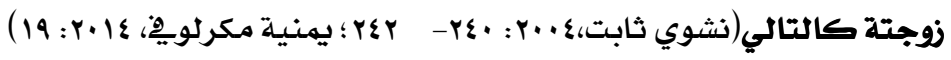

$$
\begin{aligned}
& \text { • العادات والتقاليد والفهم الخاطئ للايات الدينية. } \\
& \text { • سوء طباع الزوج والعصبية الشديدة. } \\
& \text { • تدخل أهله بصورة كبيرة. } \\
& \text { • ضعف شخصية الزوج وضغط العهمل. }
\end{aligned}
$$

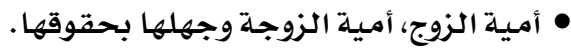

$$
\begin{aligned}
& \text { • ضعف شخصية الزوجـة أمام الزوج. }
\end{aligned}
$$

\section{ج .أسباب ترجع إلىي الأوضاع الثقافية والاجتماعية:}

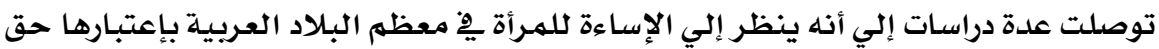

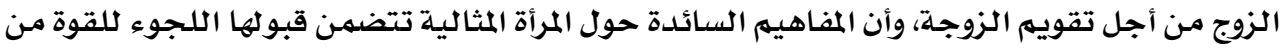

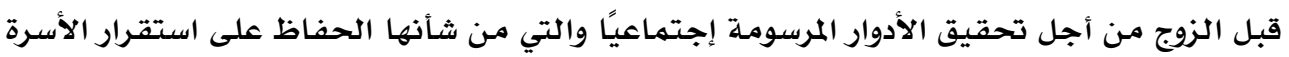

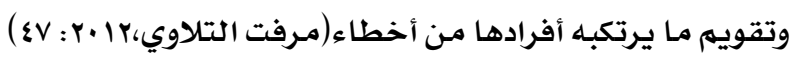
وترى الباحثة أن الموافقة الضمنية التي يهنحها المجتهـع للزوج الممارس للإساءة " الزوج

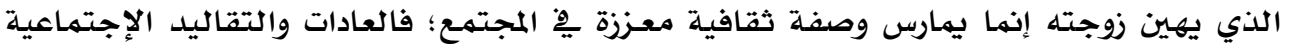

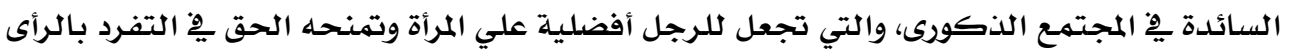

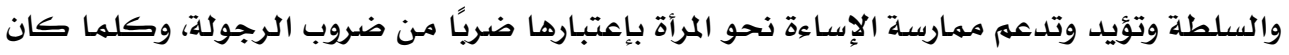

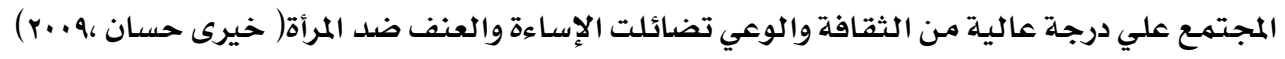

\section{العوامل المؤثرة علي قبول الإساءة الزوجية:}

تعتبر بعض المتغيرات الديموجرافية محددات للحكم علي إضطراب السلوك، فالسلوك

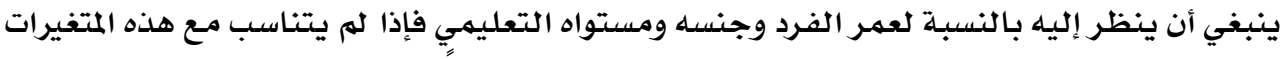

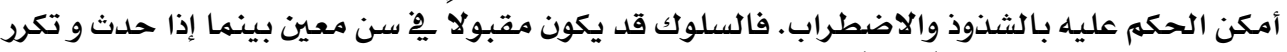

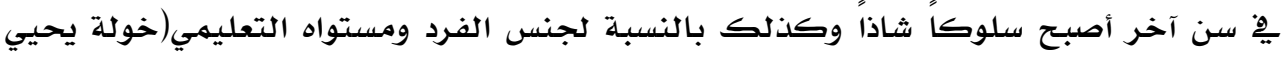

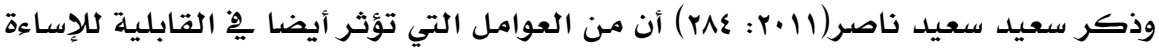

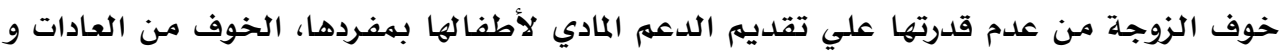


التقاليد و سؤال الأبناء دائماً عن الأب ِِ2 حالة الانفصال، اعتقاد بعض الزوجات أن الإساءة هي دليل

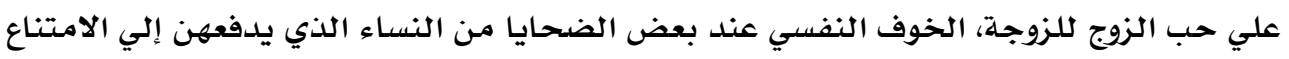

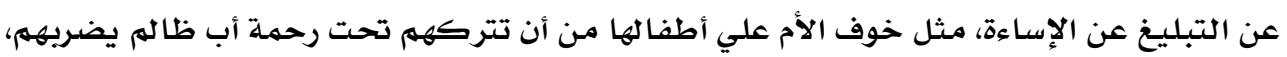

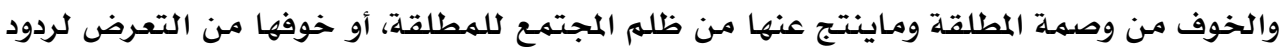

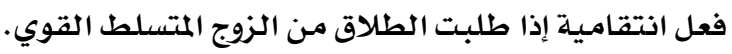

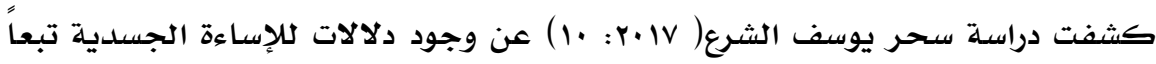

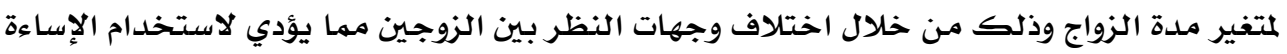

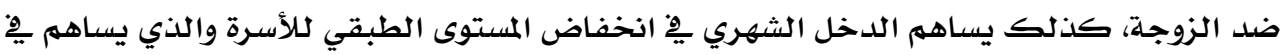

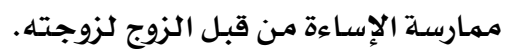

\section{اقتصر البحث الحالي علي التعرف علي آثر بعض العوامل وهي: "} - وجود الأبناء. - فارق العمر بين الزوجين.

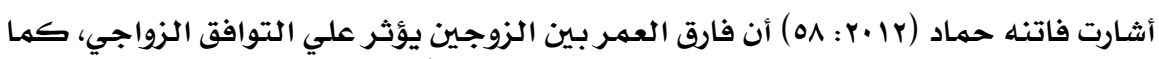

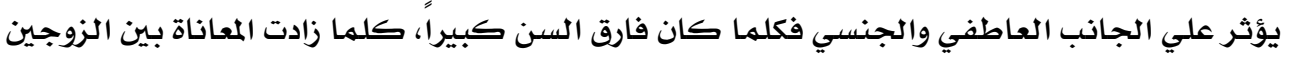

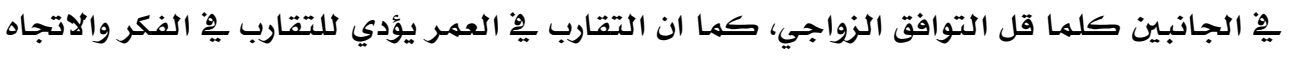

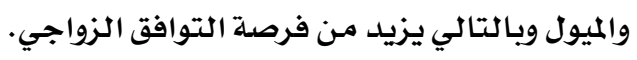

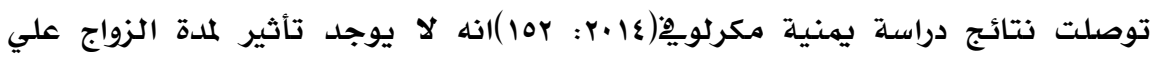

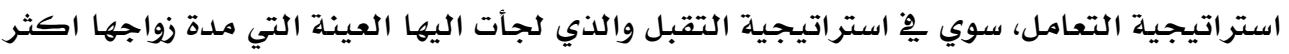

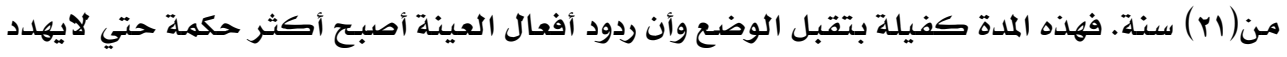

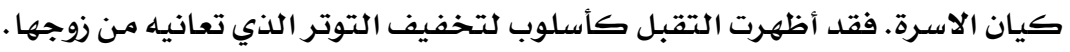

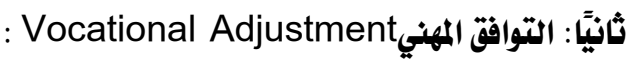

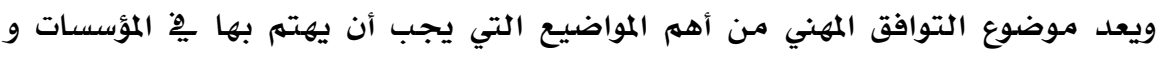

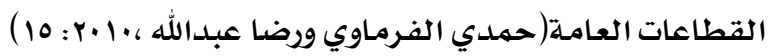
يعتبر التوافق المهني أحد جوانب التوافق النفسي العام، (مصطفى جبريل وفاروق جبريل،

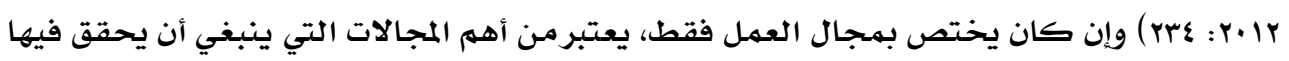
الفرد أكبر قدر من التوافق لسببين هما:

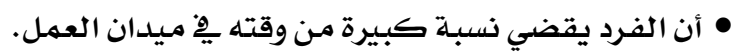

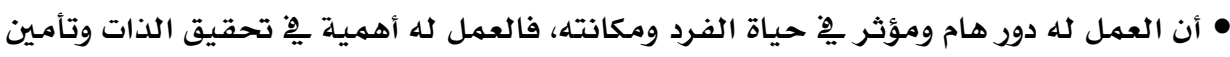

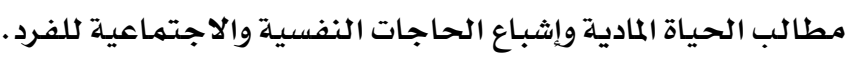
وقبل الخوض ِِ مفهوم التوافق المهني، نبدأ بالحديث عن مفهوم التوافق بشكل عام. 


\section{• مفهوم التوافق(العام، مجالاته):}

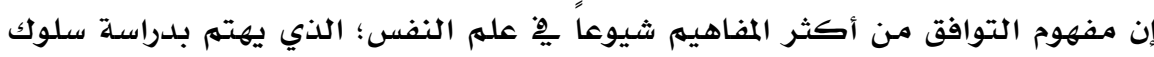

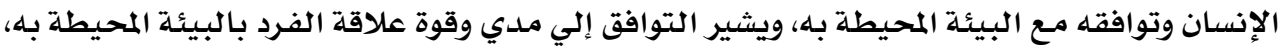

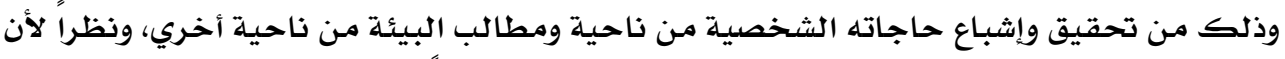

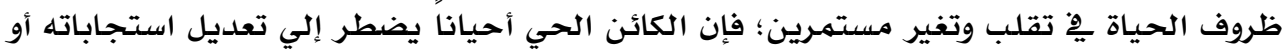

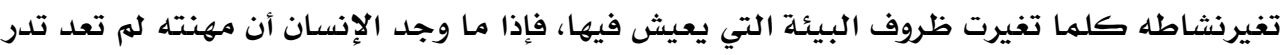

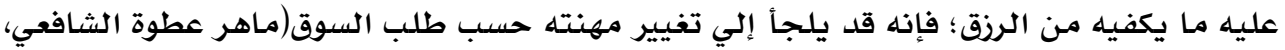

( $r$ Y $:$ Y $\cdots r$

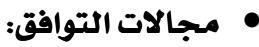

هناك مجالات كثيرة للتوافق ترجع لطبيعة العلاقة بين الفرد والبيئة والتي تنشأ عن

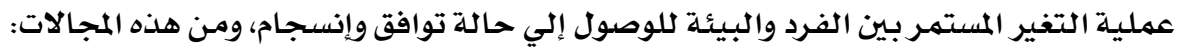

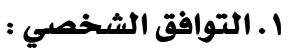

ويتضمن السعادة مـع النفس والرضا عن النفس واشباع الدوافع والحاجات الداخلية

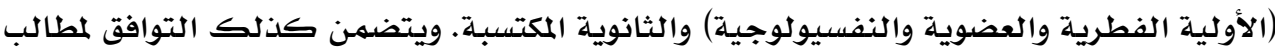

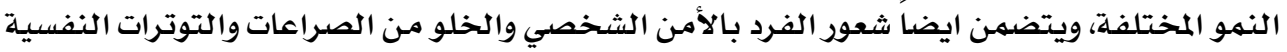

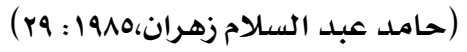

كما أن التوافق الشخصي يتمثل فى مجموعة الاستجابات المختلفة التى تدل على تمتع ألفا

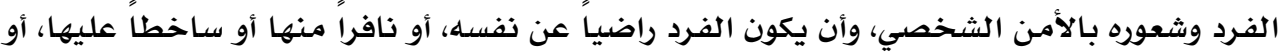

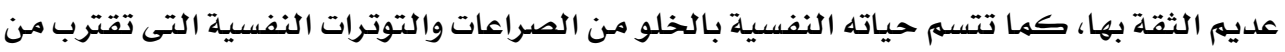

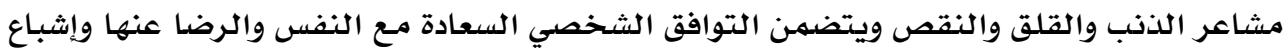

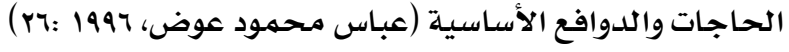

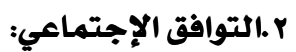

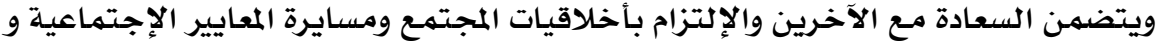

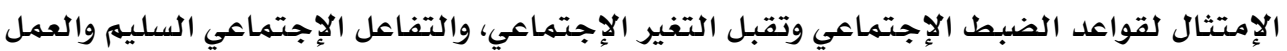

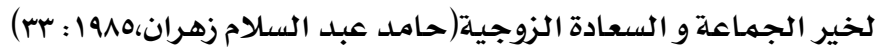

المقصود بالتوافق الاجتماعي هو قدرة الفرد علي إنشاء علاقات اجتماعية سليمـة. حيث

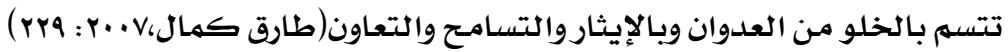

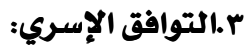

يتضمن السعادة الأسرية التي تتمثل ِِّ الاستقرار الأسـري والتماسك الأسـري، قدرة الفرد

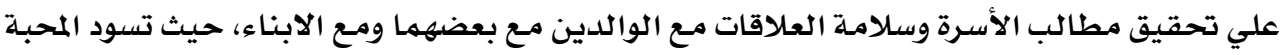




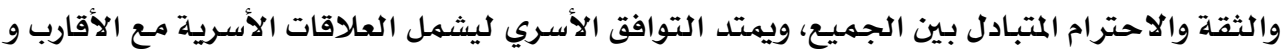

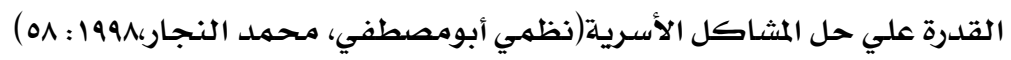

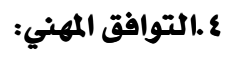

يعتبر التوافق المهني أحد مجالات التوافق العام، فحياة الإنسان موزعة يِّاِ أغلبها بين الحياة

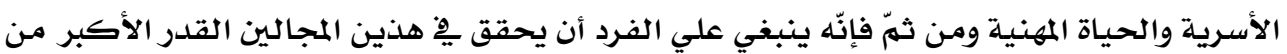

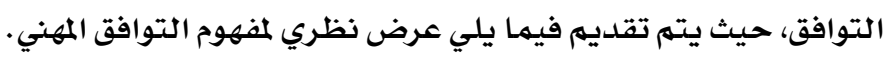

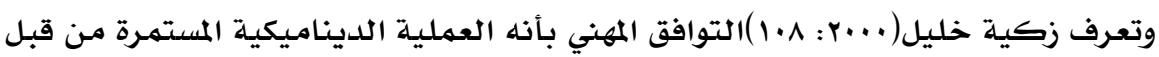

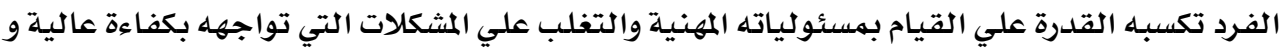

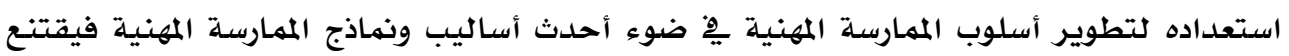

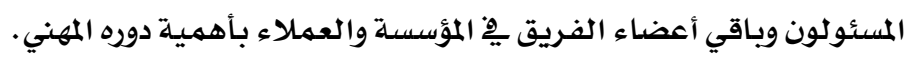

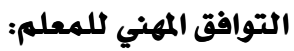

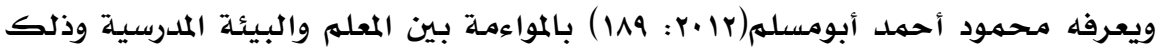

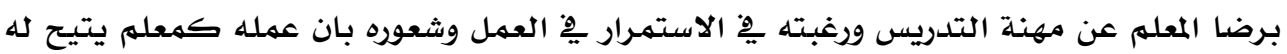

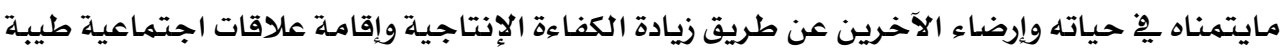

$$
\text { مـع الزملاء مايتاه }
$$

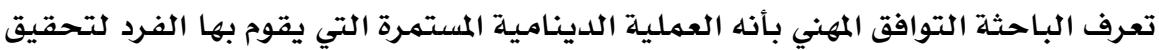

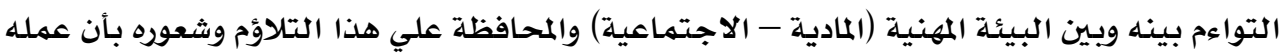

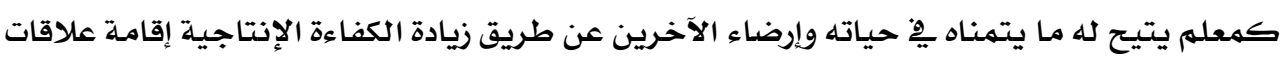

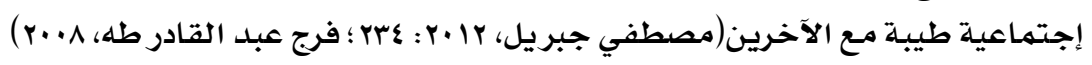

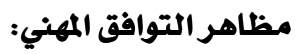

يمكن الاستدلال علي التوافق المهني من خلال نتائجه، وإحدى هلذه النتائج هي الرضا

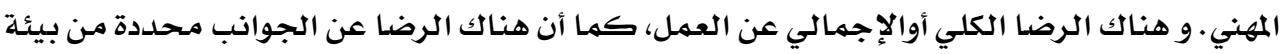

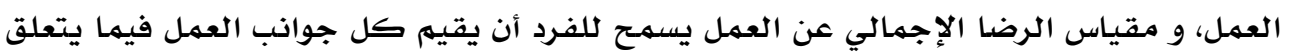

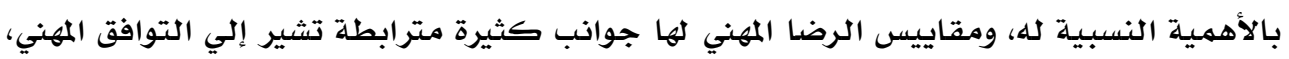

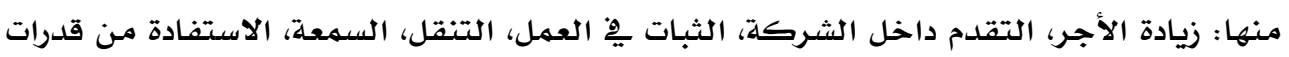

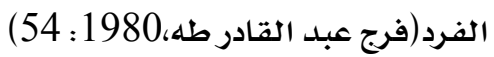
ويظهر التوافق مِِ الأبعاد التالية:

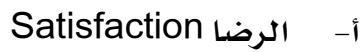

ب- الإرضاء الرضاء ج- الحالة الصحية والنفسية للمعله. 


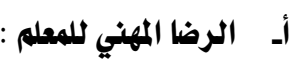

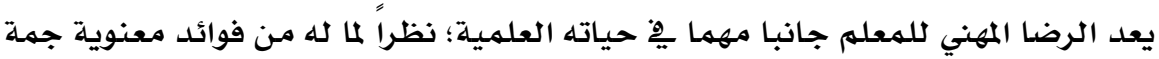

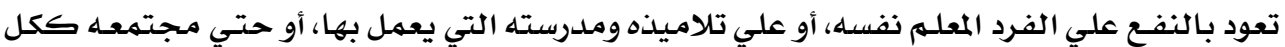

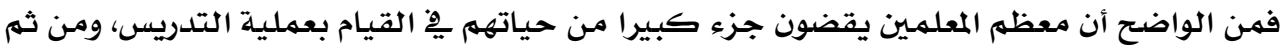

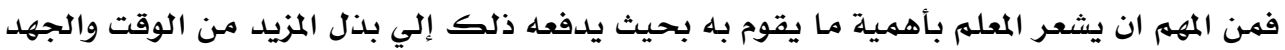

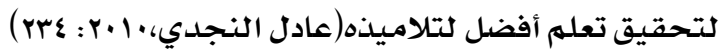

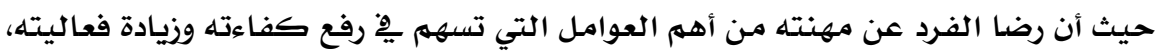

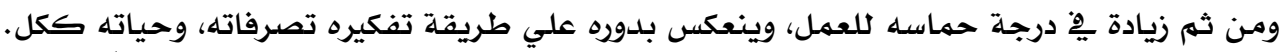

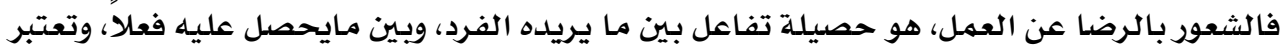

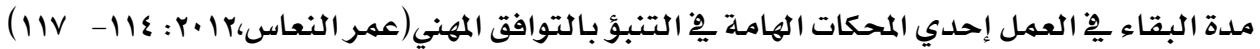

\section{ويظهر الرضا المهني للمعلم فيما يلي:}

العامل مـع رؤساء العمل وزملائه، إدركه لظروف العمل، نظرة المعله للمـردود المادي، ادركها

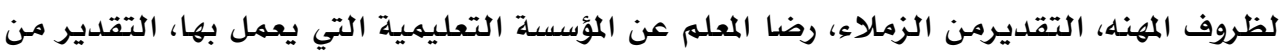

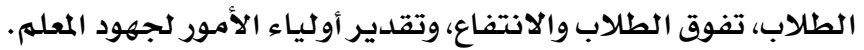

بـ الإرضاء المهني للمعله:

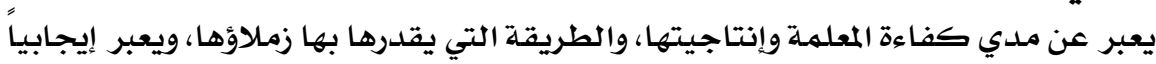

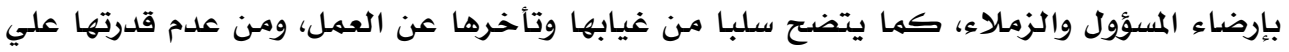

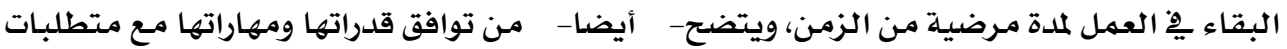

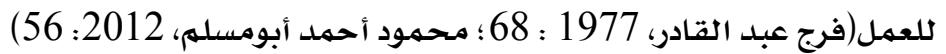

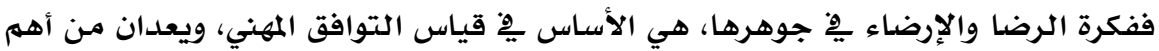

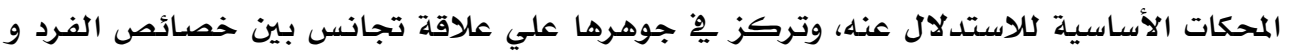

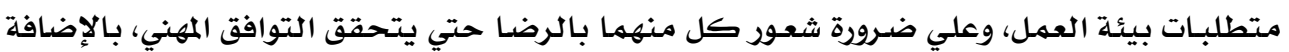

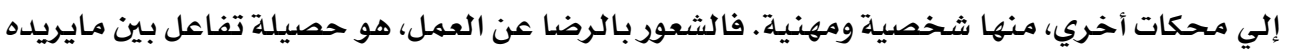

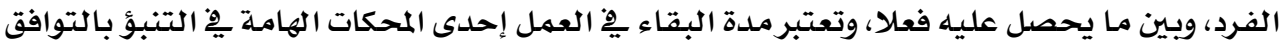

\section{ويظهر الإرضاء المهني للمعلم فيما يلي:}

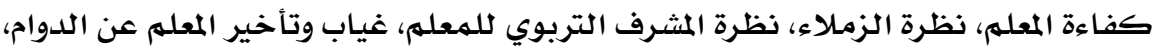

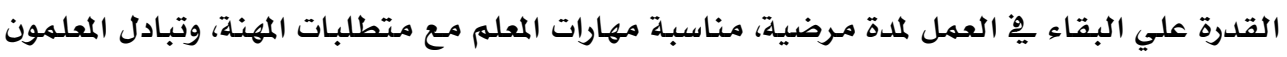

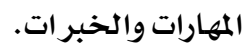


جـ الحالة الصحية والنفسية للمعله.

أن للحالة النفسية مؤثرات ومظاهر تدل عليها، ويتوافر العديد منها لدى الفيه الفرد الذيى

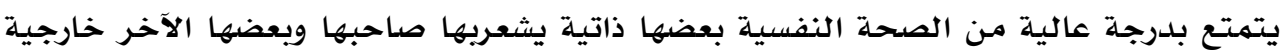
يدركها الآخرون ومن مظاهر الصحة النفسية (أديب الخالدي، 2002 : 202 : 70 )

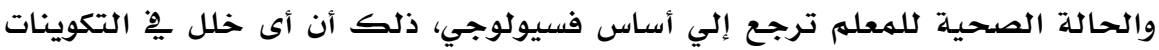

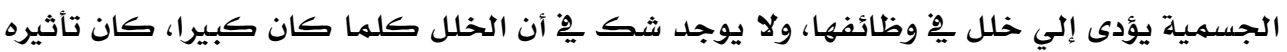

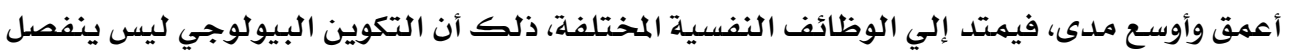

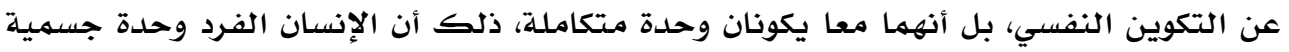

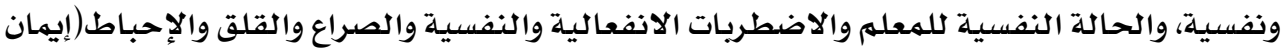

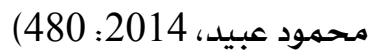

\section{ومن مظاهر الحالة الصحية والنفسية للمعلم مايلي:}

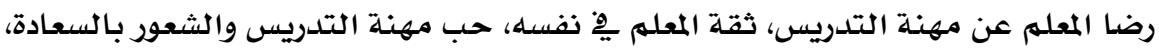
كراهية المهنة وظهور الاضطرابات والتوترات، الشعور بالأمن والأمان، وظهور الاضطرابات الأبهات الانفعالية، ظهور القلق والإحباط والصراع. • خصائص التوافق المهني:

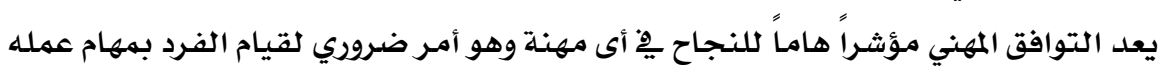

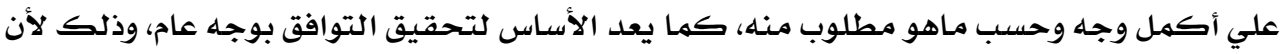

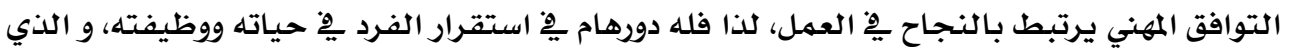

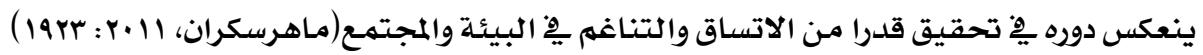

• التوافق كعملية:

يهتم بفهم العمليات والتي يمكن للفرد أن يحقق بها توافقه مـع بيئة العمل و تحقيق حالة

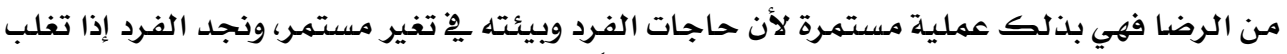

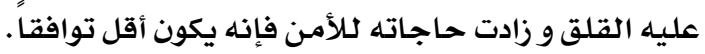

• التوافق كإنجاز:

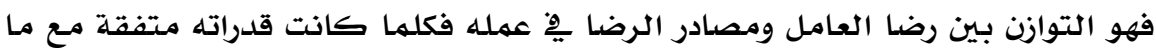

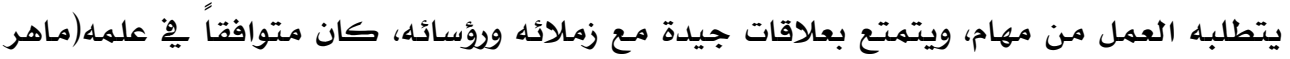

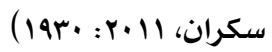
• التوافق كحالة :

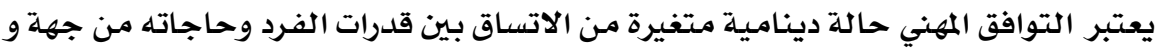

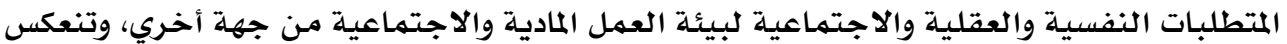

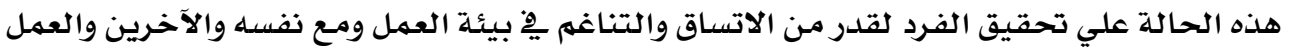


ذاته. ويعرف التوافق المهني وفقا لهذا المنحني علي أنه حالة من الاتسـاق مـع نسق التنظيه، وأنه عملية

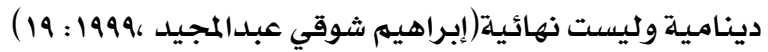

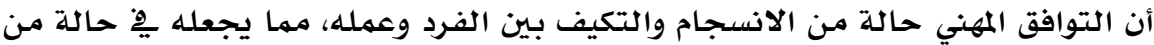

الرضا والارتياح، وتتعلدد مظاهره منها ما يتعلق بالعمل مثل زيادة الإنتاجية والانتظام وِّ العهل. ويري "ولمان Woolman" أن التوافق المهني يشير إلي علاقة اتساق مـ البيئة، و هذا يتضمن

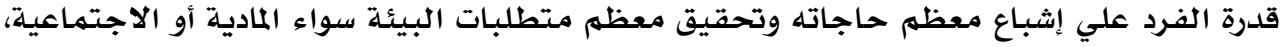

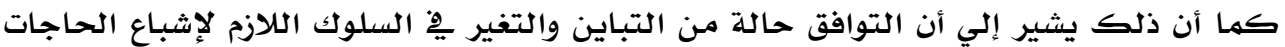

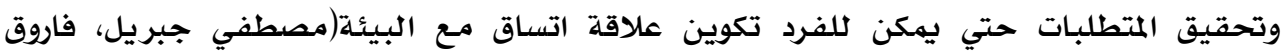

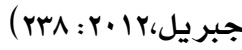

\section{المتطلبات النفسية للتوافق المهني:}

ففعالية العمل تتوقف إلي حد كبير علي كفاءة الفرد ؛ لأن تقدم نظم العمل مـرهون بأداء

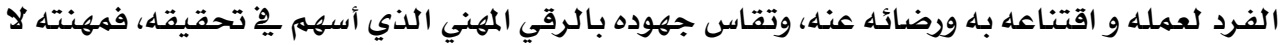

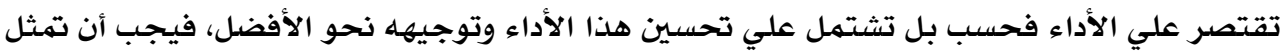

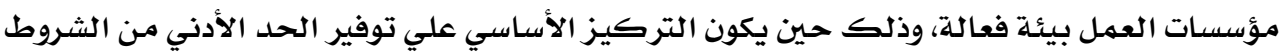

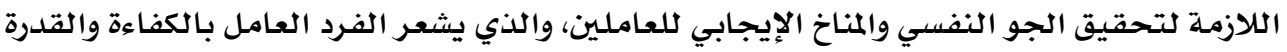

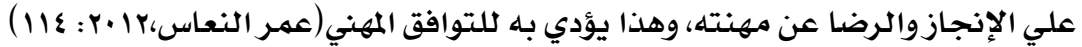

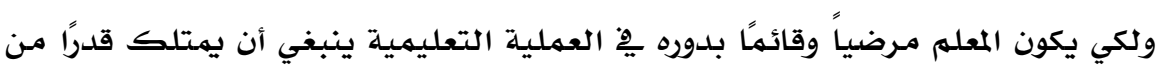

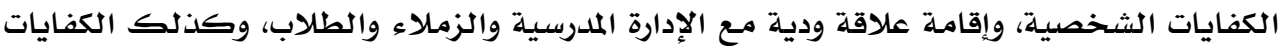

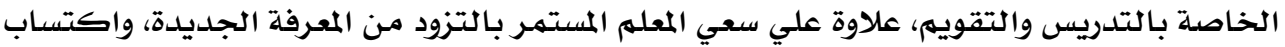

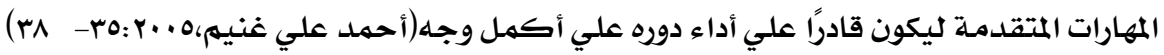
العوامل المؤثرة علي التوافق المهني:

يؤثر يِّ التوافق المهني للفرد بشكل عام العديد من العوامل و المتغيرات أوضـح سارجنت

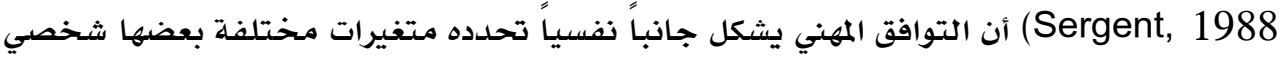
وبعضها الآخر متصل ببيئة العمل وظروفه من حيث وجود تحديات مهنية فيه علاوة على عوامل

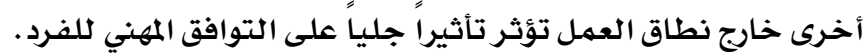

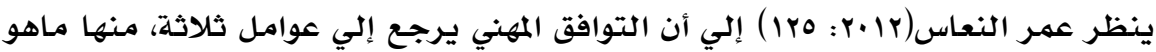

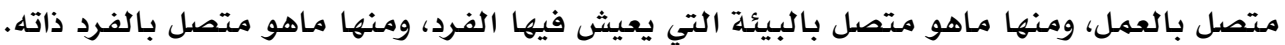

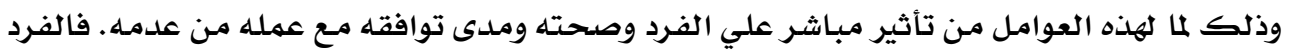

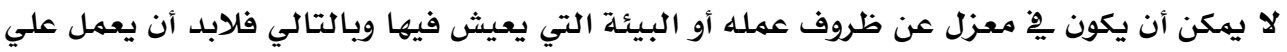

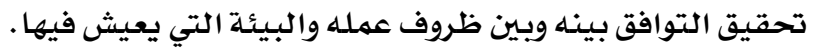


هناك اختلاف بين تأثير عوامل التوافق من فرد لأخر، وذلك لأختلاف البناء أو التنظيم

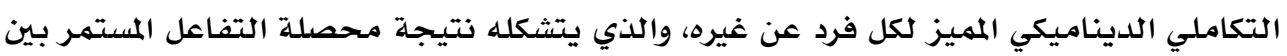

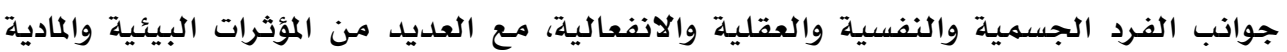

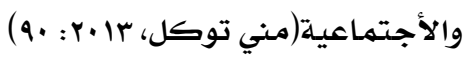

\section{• سوء التوافق المهني Vocational Negative Adjustment:}

وسوء التوافق المهني هو عجز العامل عن التكيف السليهم لظروف عمله المادية أو الاجتماعية

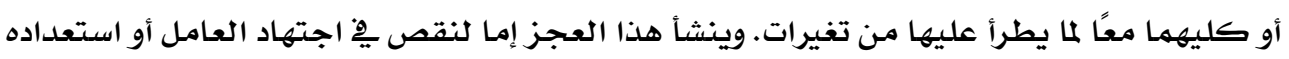

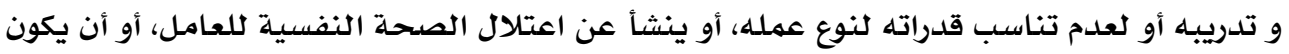

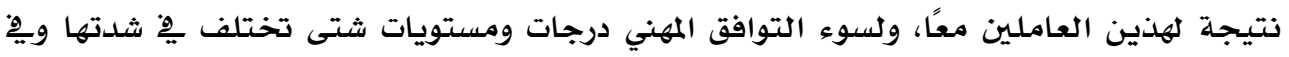

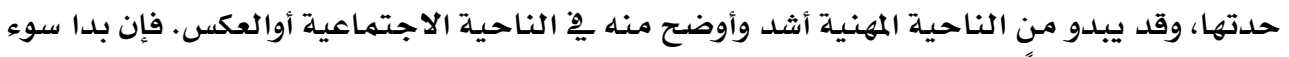

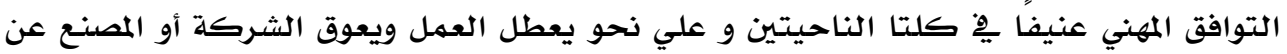

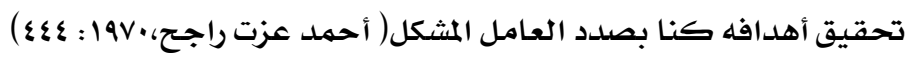
تعريف سوء التوافق المهني:

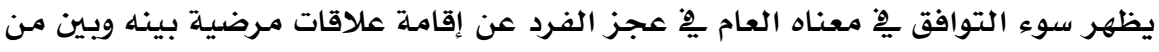

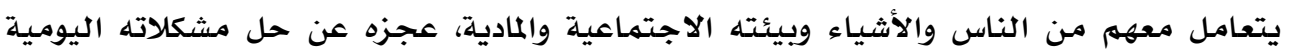

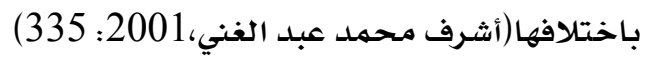
أسباب سوء التوافق المهني(النتائج المترتبة عليه):

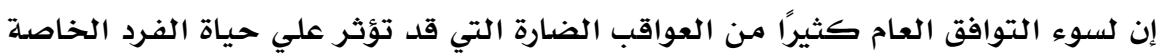

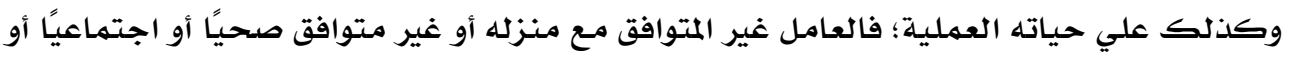

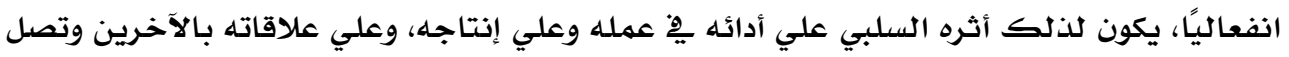

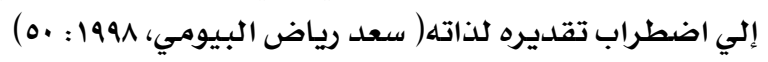

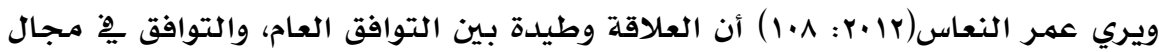

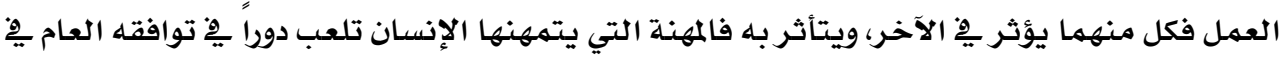
الحياة، وكذلك فِ سوء توافنها يؤنه.

وهناك أسباب عديلة تكمن وراء ظاهرة سوء التوافق المهنى لدى العاملين ومن هذه الأسباب ما يلي:

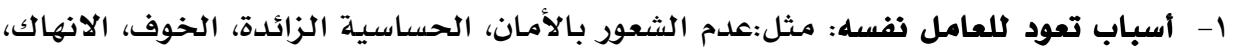

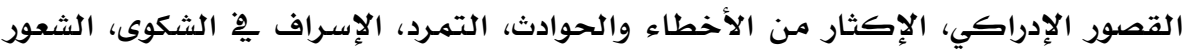

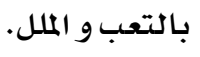

ץ- أسباب تعود للعمل: مثل سياسات التدريب والتوظيف، نهط الإدارة والإشراف، سياسة الترقي

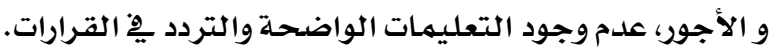




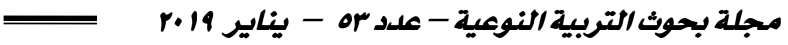

r- أسباب تعود للبيئة: تتعلق بالبيئة التي يعيث فيها العامل ِِّ الأسرة و المجتمع وغير الملائمسة

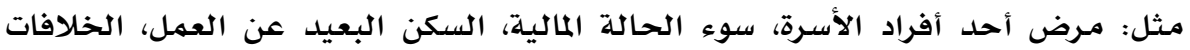

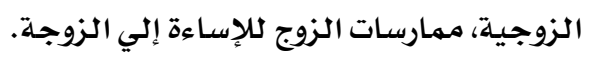
• النتائج المترتبة علي سوء التوافق المهني:

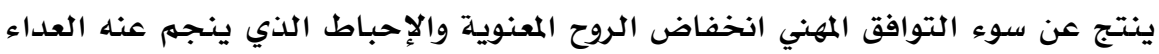

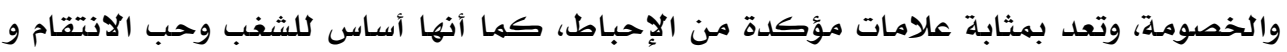

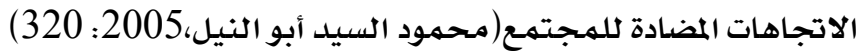

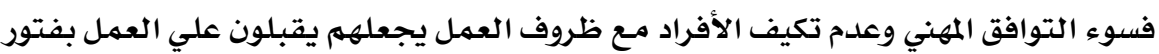

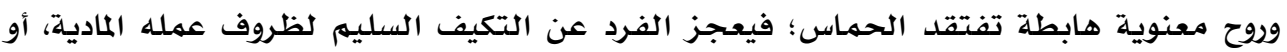

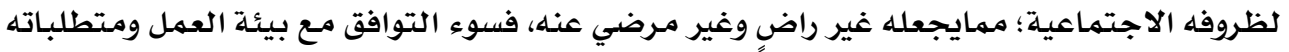

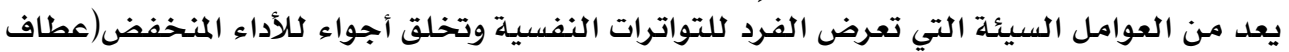

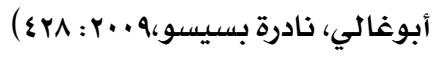

مهنة التدريس من أكثر المهن المعرضة للضغوط لما تتطلبه من أعباء ومسئوليات، فالمعلم المهات

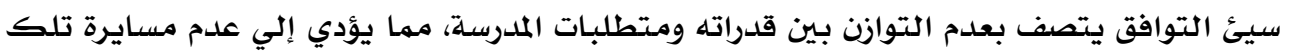

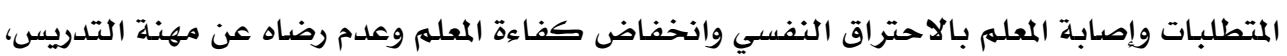

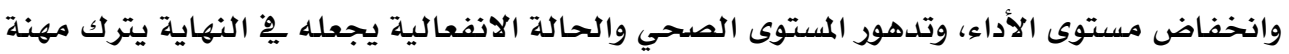

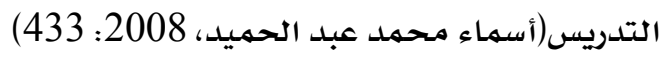
مظاهر سوء التوافق المهني للمعله:

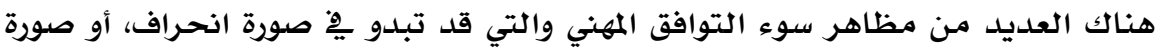

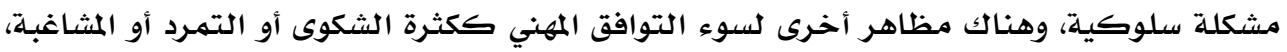

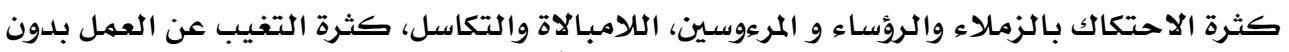

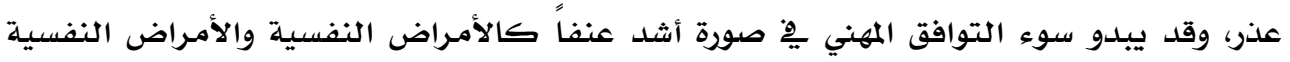

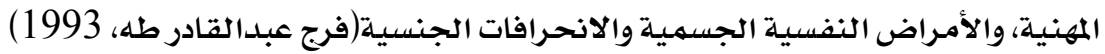

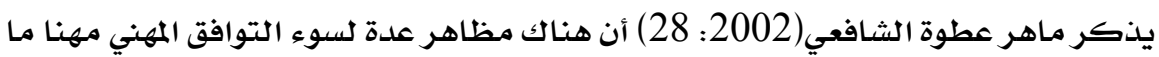

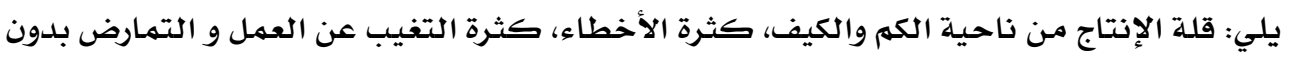

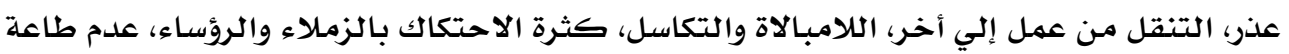
تعليمات المؤسسة. طرق تحقيق التوافق المهني لدي المعلمين:

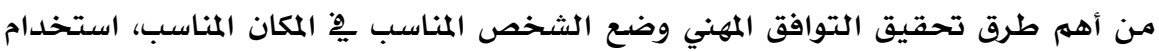

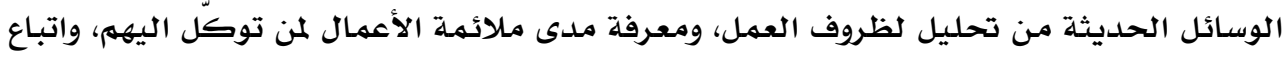

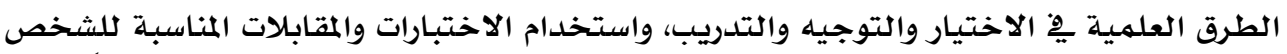

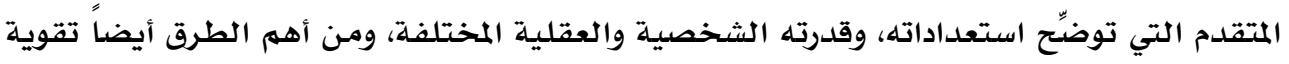


علاقة الموظف بمؤسسته و ذلك من خلال دراسة مشكلات الموظفين والضغوط النفسية التي

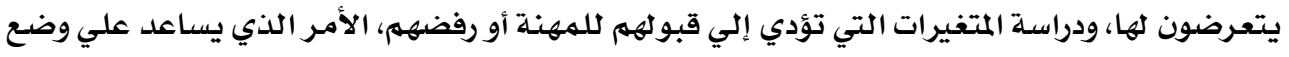

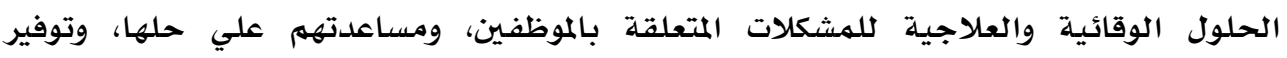

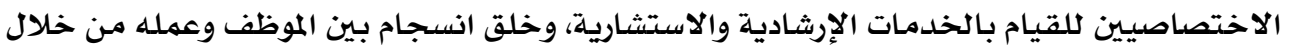

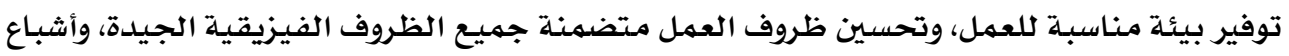

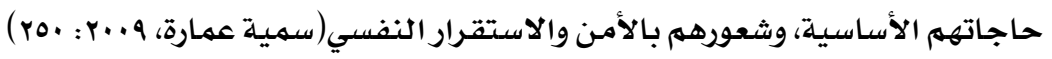

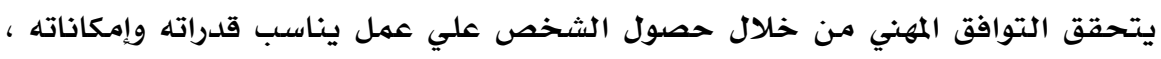

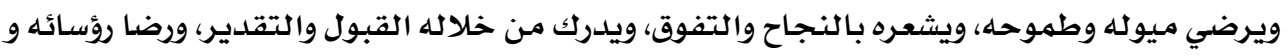

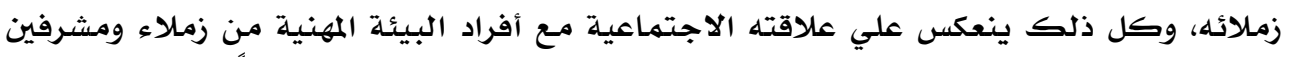

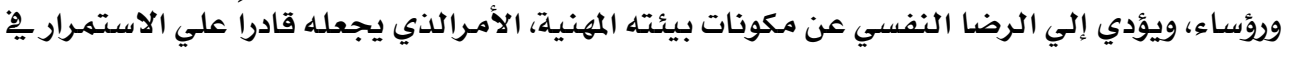

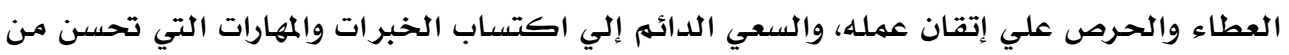

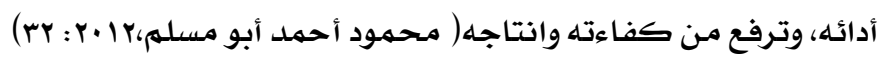

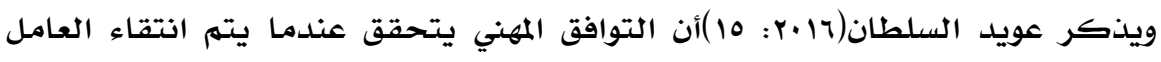

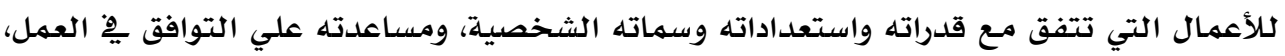

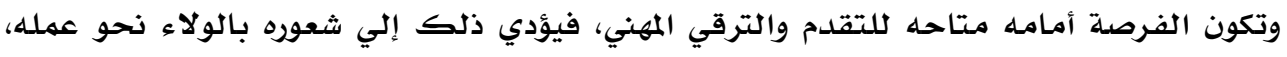
ويتحقق ارتباطه بمهنته.

\section{ثالثاً: العلاقة بين القابلية للإساءة الزوجية وبلة والتوافق المهني.}

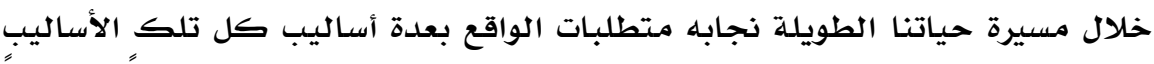

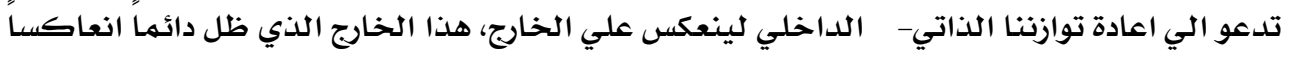

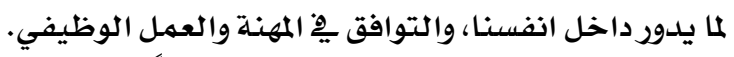

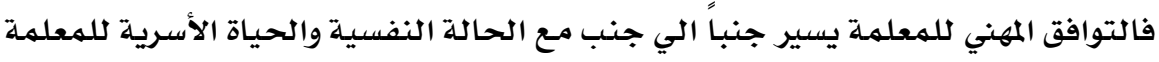

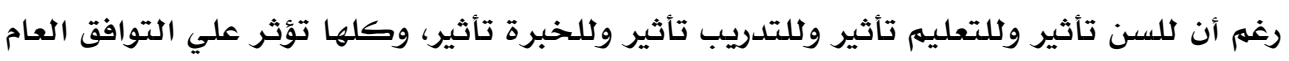

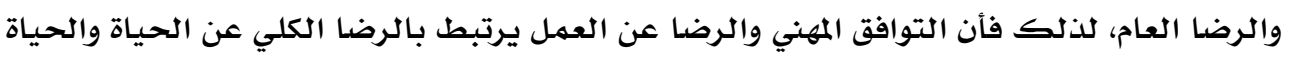

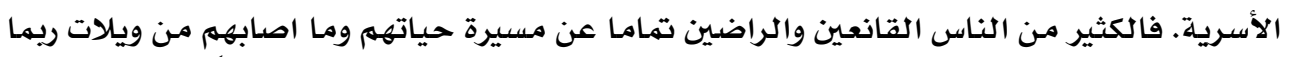

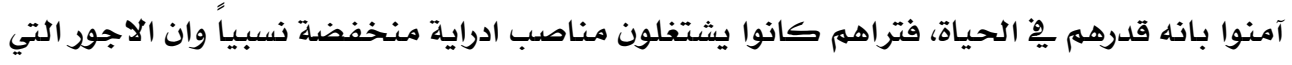

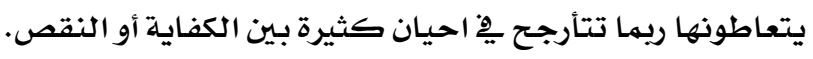

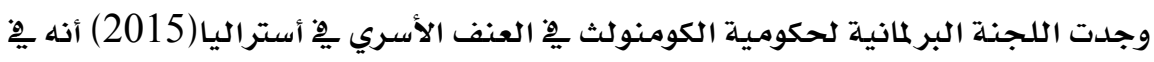

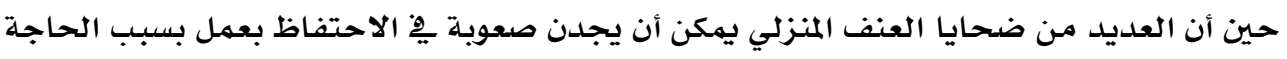

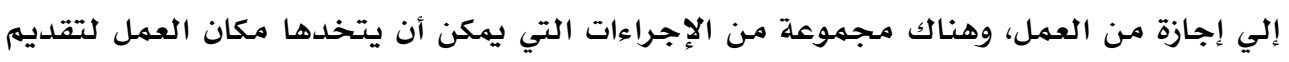

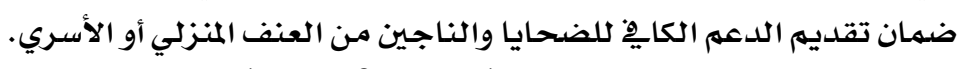

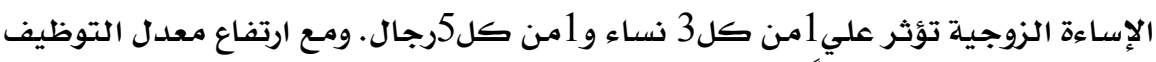

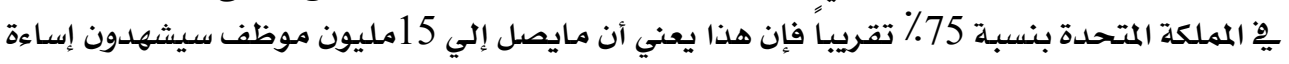




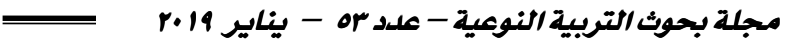

زوجية خلال الأشهر212المقبلة. وهذا يكلف الأقتصاد البريطاني مايقرب من ملياري جنيه استرليني

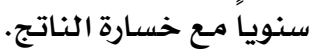

كها ينتج عن ممارسة الإساءة الزوجية عدم قدرة المرأة العاملة علي الإبداع والتركيز

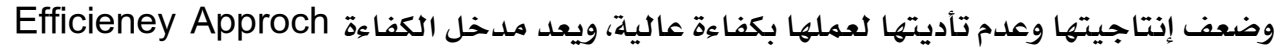

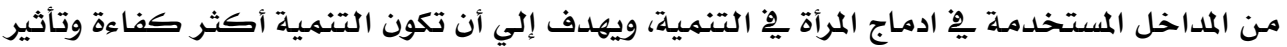

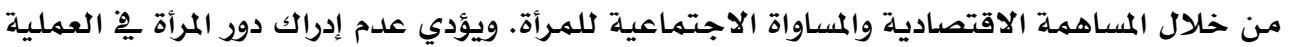

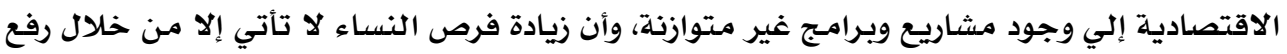

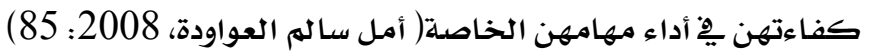
وكما ذكرت دراسة ماكجريجور(Macgregor et al,2015) أنه أجري مسحاً عبر الإنترنت بخصوص تأثيرات العنف المنزلي ِِّ العمل. وكانت النتائج أن أكثر من ثلث دانث المستجيبين

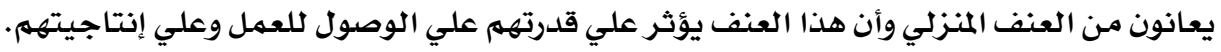
الدراسات السابقة: دراسات تتعلق بعلاقة القابلية للإساءة الزوجية بالتوافق المهني:

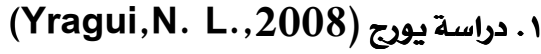

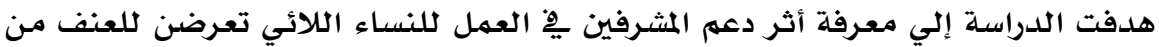

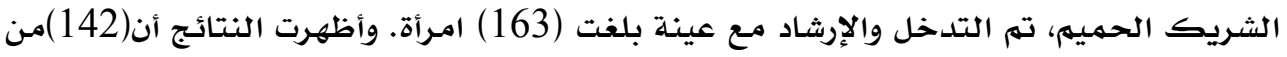

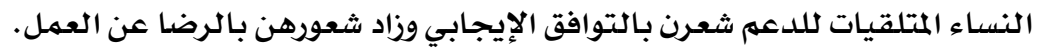

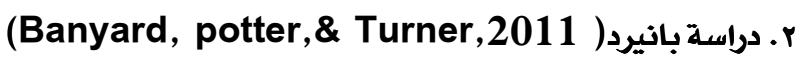

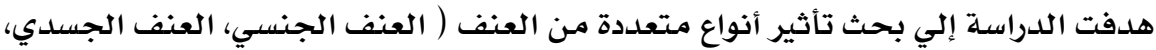

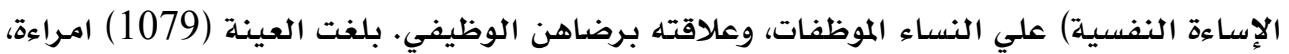

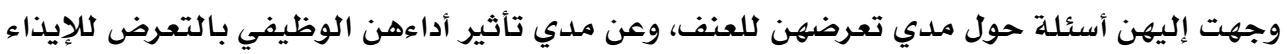

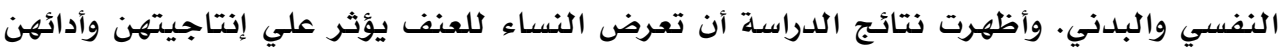
ورضاهن الوظيفي.

r. م. دراسة ريفيز)(2012) هدفت الدراسة التعرف علي أثرعنف الشريك الحميمي علي النساء يْ مجال عملهن،

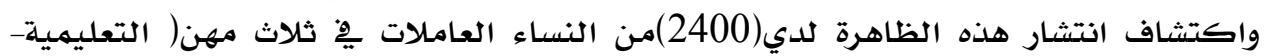

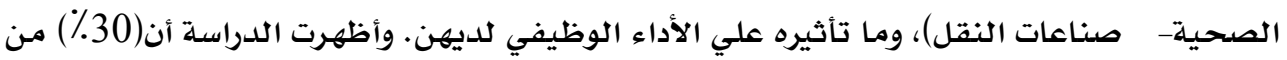

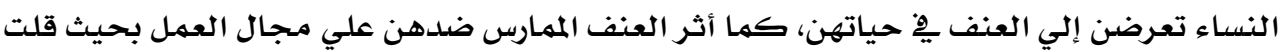
إنتاجيتهن وعدم القدرة علي مواصلة العمل. العين. ع. دراسة ماكجريجور Macgregor, Macquarrie,\& Wathen ( 
هدفت الدراسة التعرف علي أثر تعرض الموظفين للعنف المنزلي، بلغت عينة الدراسة)

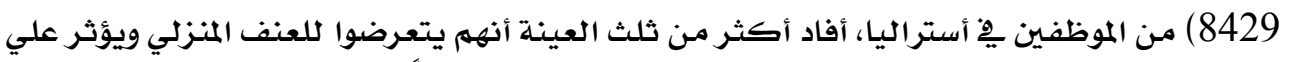

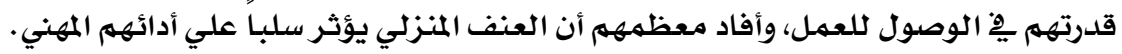

ه. دراسة شوالتر(Showalter, K.,2016)

هدفت الدراسة إلي مراجعة الدراسات السابقة حول العلاقة بين العنف الأسري وعدم العدام

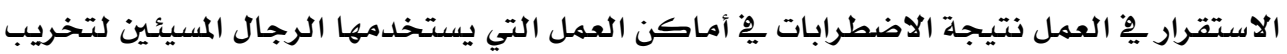

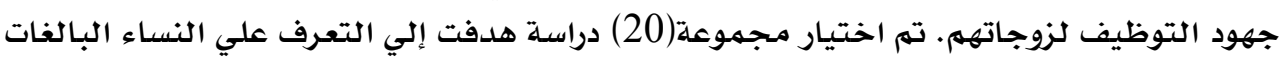

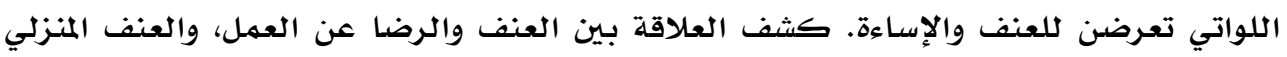

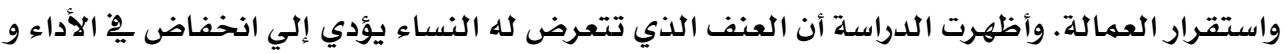

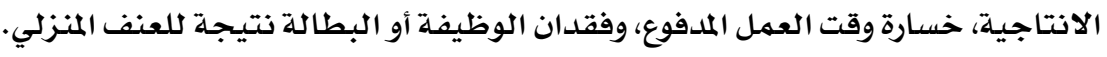

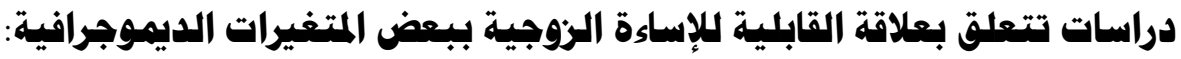

ا ـ دراسة يونت (Yount,2005)

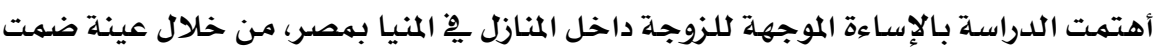

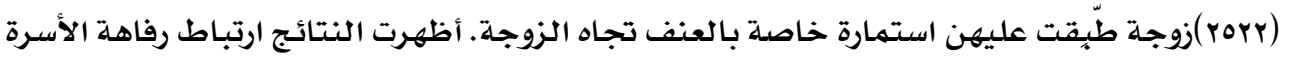

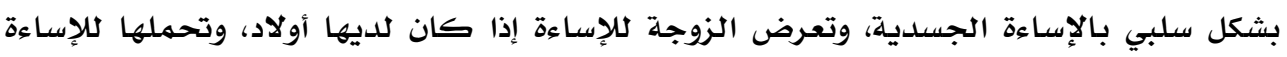
بلدرجة كبيرة.

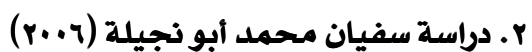

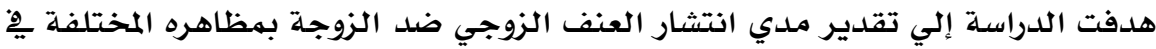

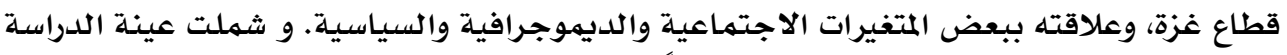

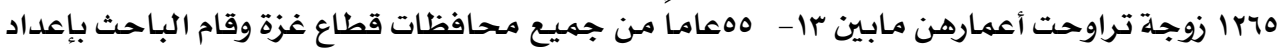

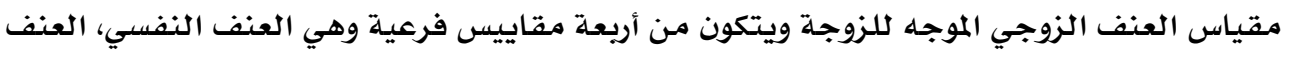

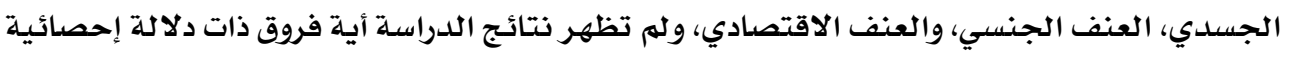

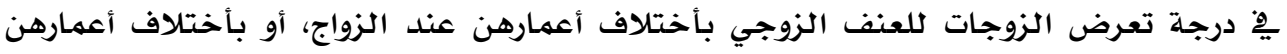

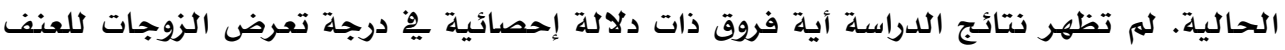

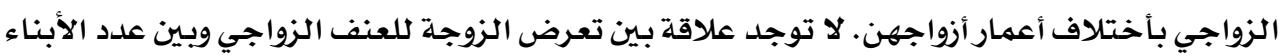

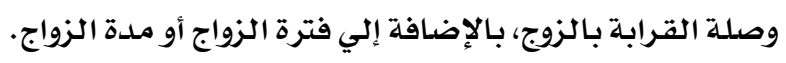

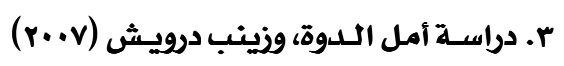

هدفت إلى محاولة إلقاء الضوء علي شخصية النساء اللاتي يتقبلن أويتحملن الإساءة

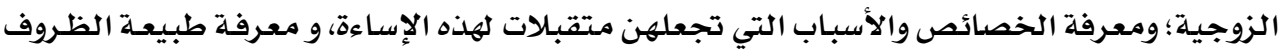

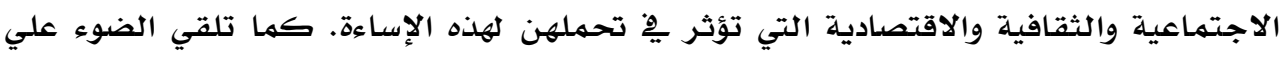

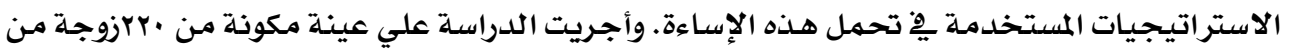


مختلف محافظات جمهورية مصر العربية تراوحت أعمـارهن مـابين 19- بع عامـا. واستخدمت

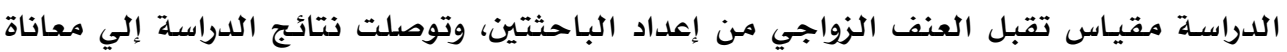

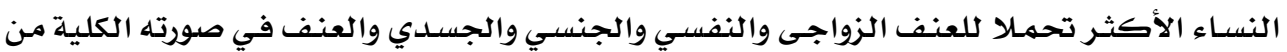

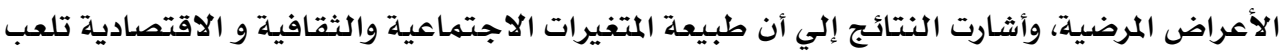

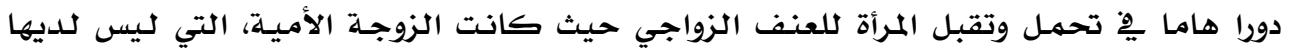

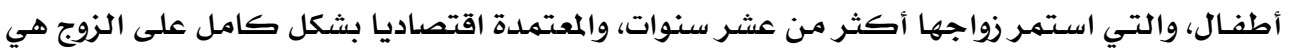
الأكثر قبولا وتحملا للعنف الزواجى.

\section{ع. دراسة عبير محمد الصبان (•r.1)}

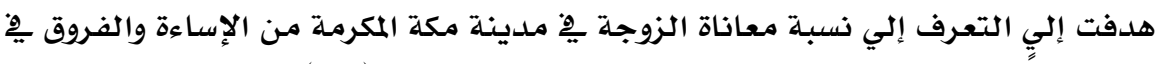

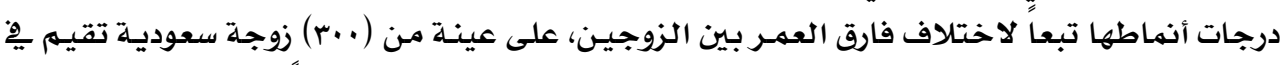

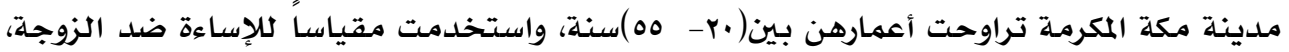

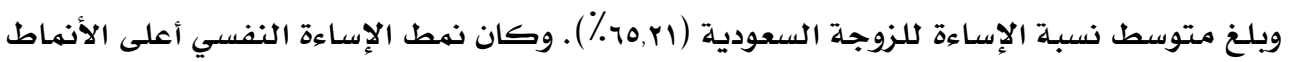

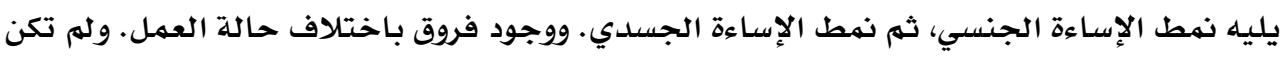

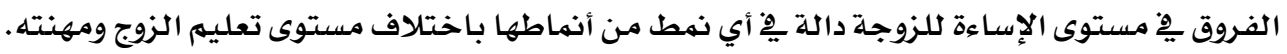

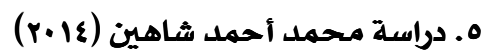

هدفت الدراسلة إلي الوقوف على واقع الإساءة الموجهة ضد الزوجات ومجالاتها يِّ محافظة

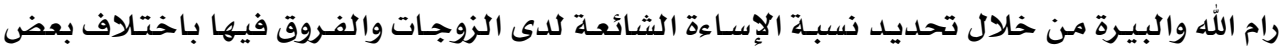

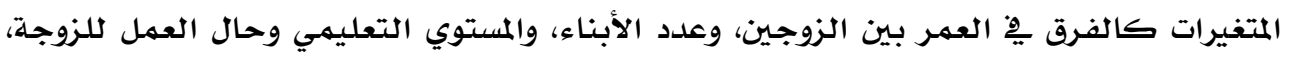

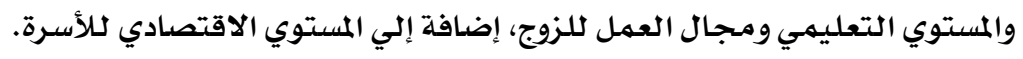

7. دراسة جمال عبد الحميد جادو (r.10)

تهدف الدراسـة إلي معرفة العلاقة بين إساءة معاملة الزوجة والاضطرابات النفسية وإمكانية

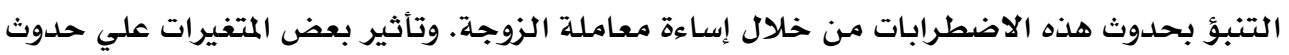

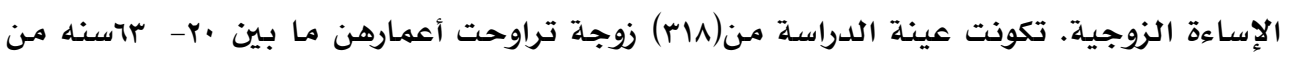

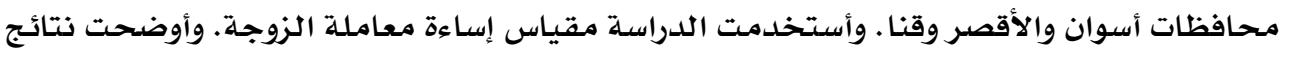

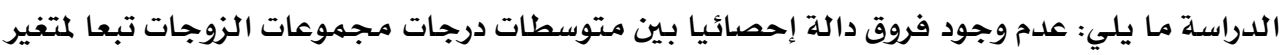

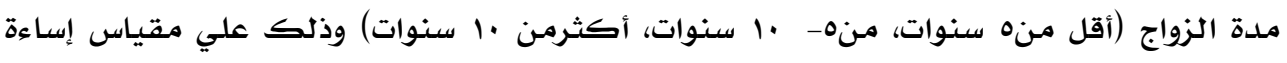

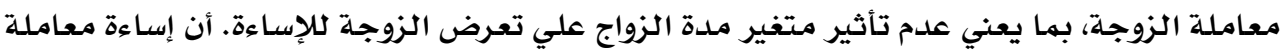

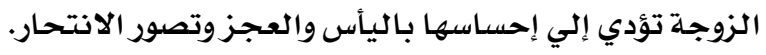

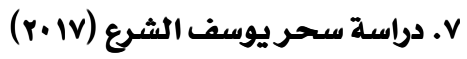

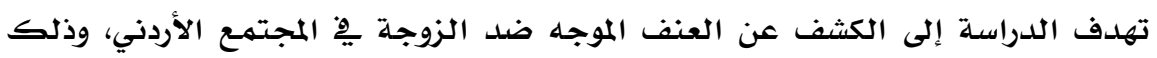

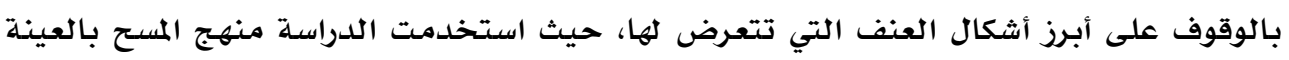


لتحقيق الأهداف، وتكونت عينة الدراسـة من ( ro ) امرأة معنفة تم اختيارهن بطريقة قصدية موزعات

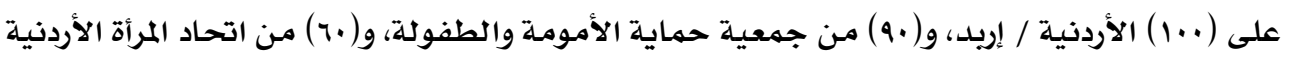

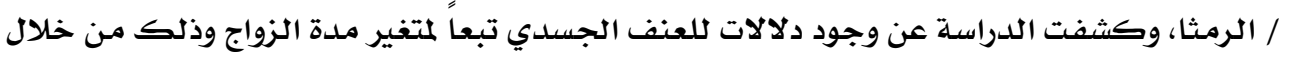

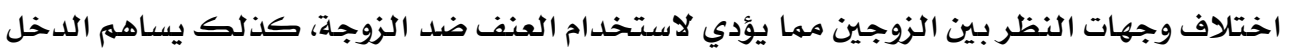

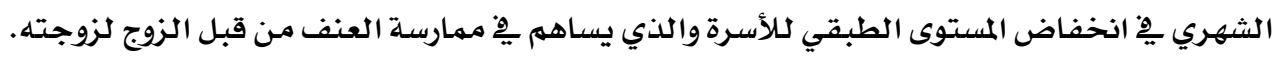

نتائج الدراسـات السابقة أوضحت: أن انتشار ظاهرة تقبل الإساءة الزوجية أمـر ملموس ـِ

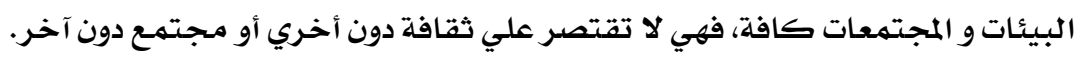

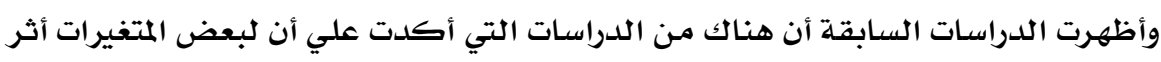

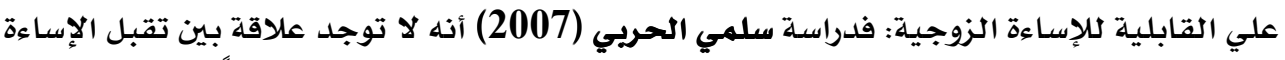

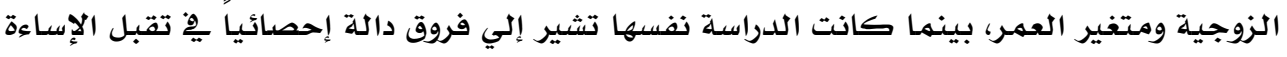

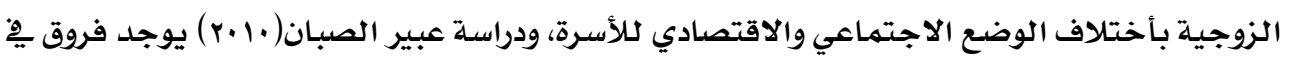

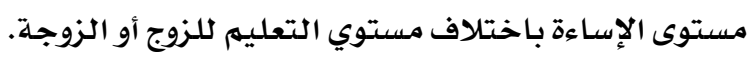

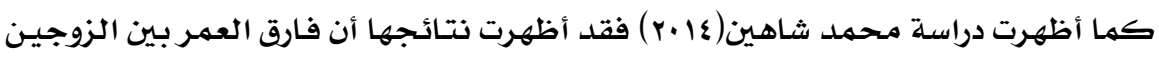

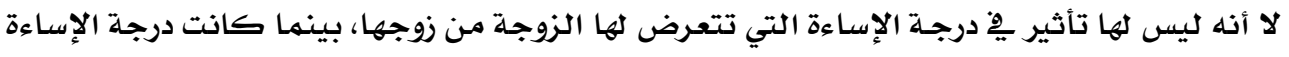

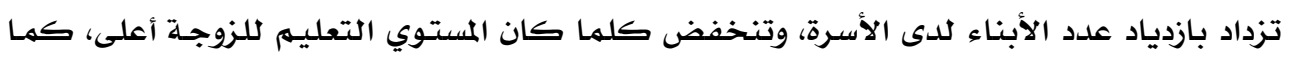

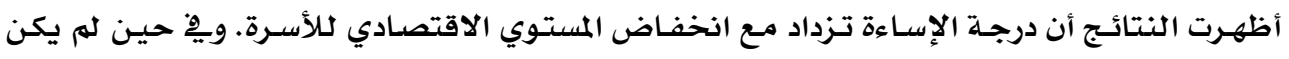

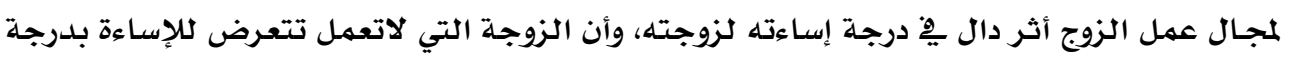
أعلى من الزوجة العاملة.

\section{التعقيب العام علي الدراسات السابقة.}

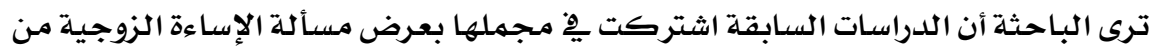

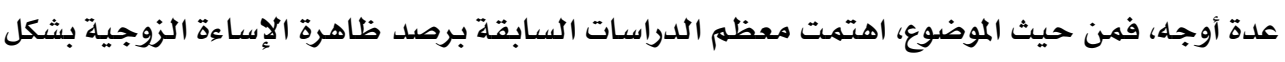

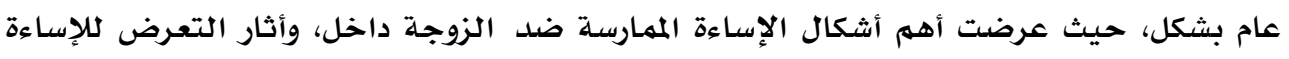

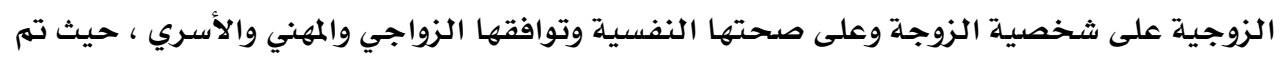
دراسة موضوع الإساءة وريطه بعدة متفيرات شخصية الزوجة وعلى فئه ونفسية.

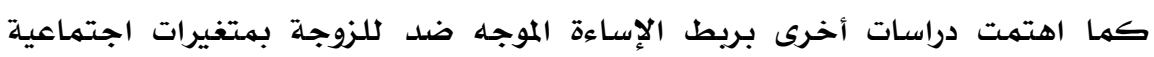

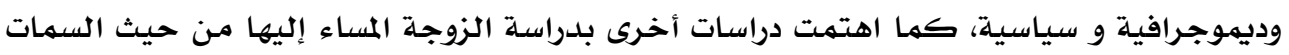

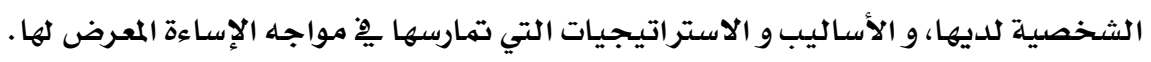

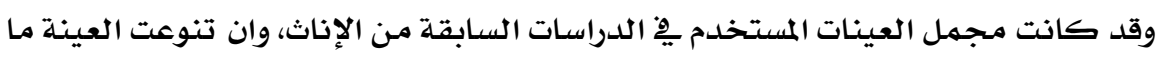

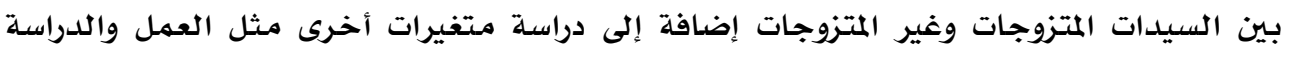

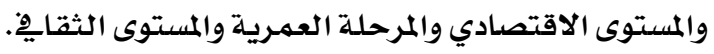


كما تبين من خلال الدراسات السابقة تنوع الأدوات والأساليب البحثية ما بين استخدام المقاييس المختلفة للإساءة ومقاييس الصحة النفسية والأساليب الإحصائية التحليلية المختلفة،

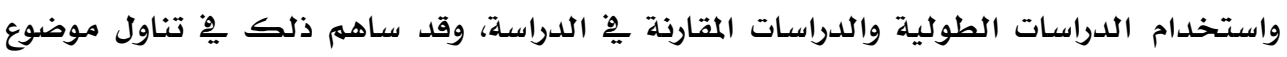

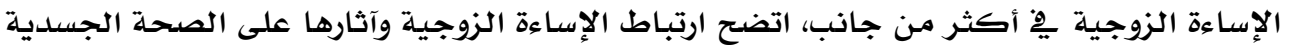

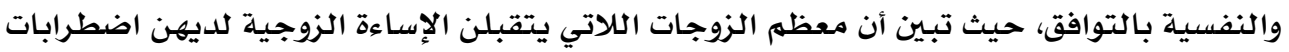

$$
\text { بالشخصية تنعكس علي توافقهن المهني }
$$

\section{فروض الدراسة:}

ا ـ توجد علاقة ذات دلالة إحصائية بين القابلية للإساءة الزوجية والتوافق المهني لدي معلمات

$$
\text { المرحلة الإبتدائية. }
$$

r. لايوجد تأثير دال إحصائياً لوجود أبناء (لايوجد أبناء- يوجد أبناء)علي درجات الإئات القابلية لالإساءة الزوجية لدي معلمات لائوات المرحلة الإبتدائية.

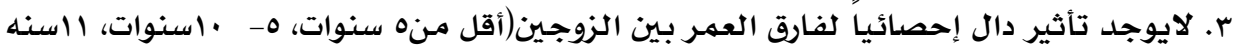

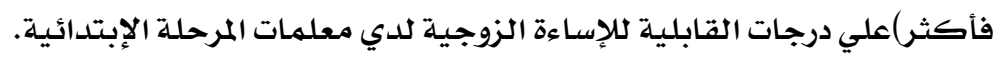

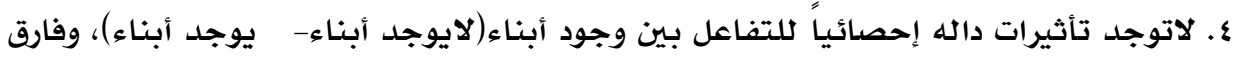

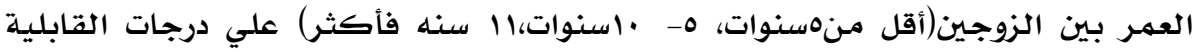
لكلإساءة الزوجية لدي معلمات المرحلة الإبتدائية.

أجريت الدراسة علي (212) معلمة من معلمات إدارة سيدي سالهم التعليمية بهحافظة كفر الشيخ ه وقسمت العينة النهائية علي مجموعتين من حيث معلمات ليس لديها أولاد ومعلمات لها أولاد.

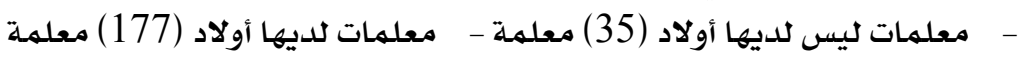

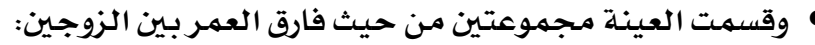

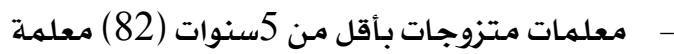

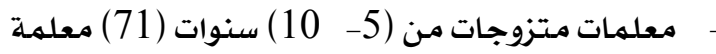

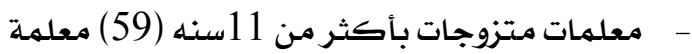




$$
\text { • مقياس التوافق المهني(إعداد الباحثة) }
$$

وتأكدت الباحثة من صدق المقياسين ويمكن الرجين الرجوع الي رسالة الباحثة للحصول علي درجـة الماجستير ·

\section{نتائج البمث وهناقشتهيرها وتفسيرها:}

الفرض الأول وينص علي: توجد علاقة ارتباطية ذات دلالة إحصائية بين درجات القابلية

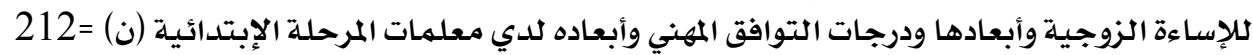
وللتحقق من هذا الفرض تم استخدام المعادلة العامـة لحساب معامل الارتباط البسيط

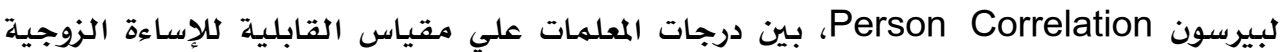

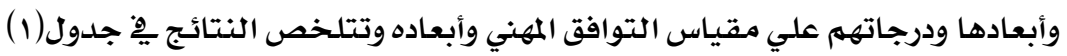

(1) جدول

معاملات ارتباط بيرسون بين درجات العينة علي مقياس القابلية للإساءة الزوجية وأبعادها ودرجاتهم علي مقياس التوافق المهني وأبعاده

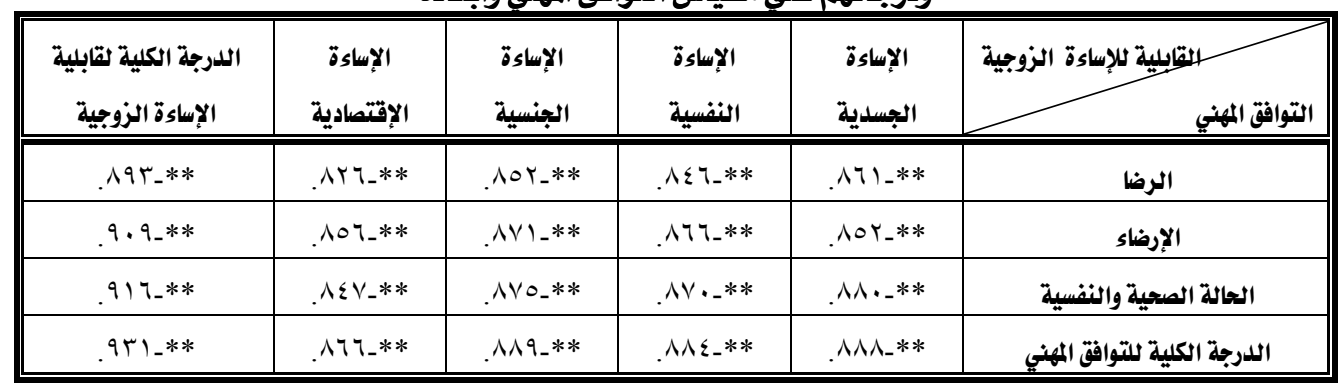

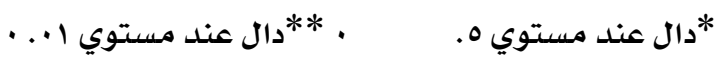

ويوضح جدول (1) قيم معاملات الارتباط ودلالتها بين أبعاد مقياس القابلية للإساءة

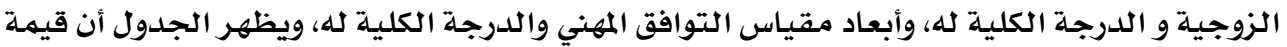

$$
\text { معامل الارتباط الزوجئ الدرجل }
$$

بين الدرجة الكلية لمقياس القابلية للإساءة الزوجية والدرجة الكلية لمقياس التوافق المهني

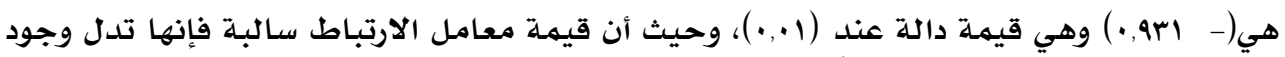

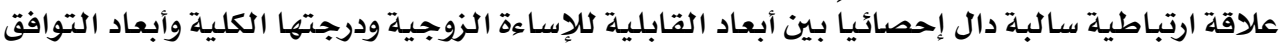

المهني ودرجته الكلية لدي معلمات المرحلة الإبتدائية.

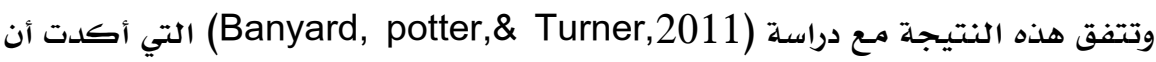

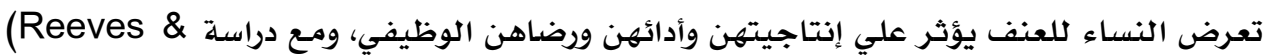
قالت O’leary- Kelly, 2012)

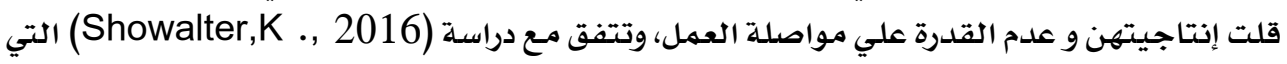




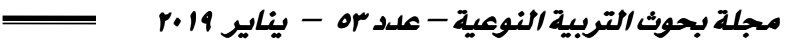

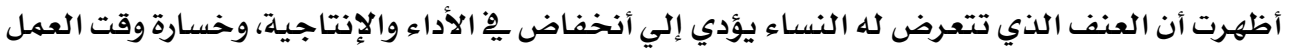

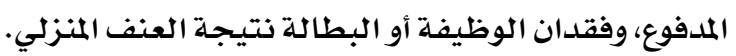

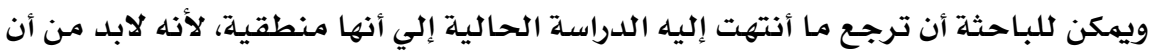

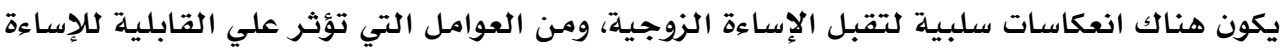

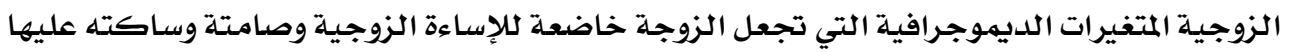

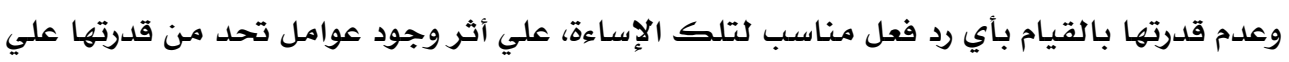
ذلك.

الفرض الثاني وينص علي أنه: لايوجد تأثير دال إحصائياً لوجود أبناء (لايوجد أبناء -

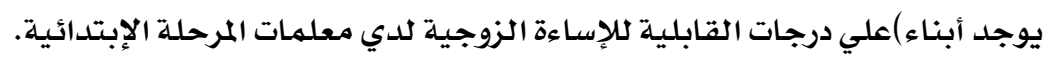

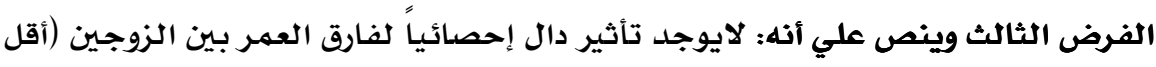

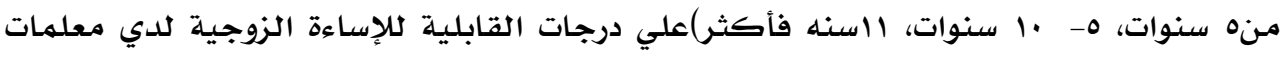
المرحلة الإبتدائية.

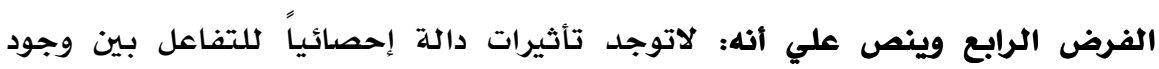

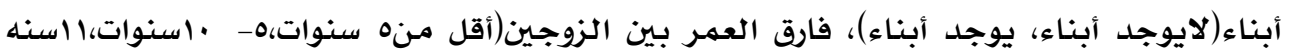

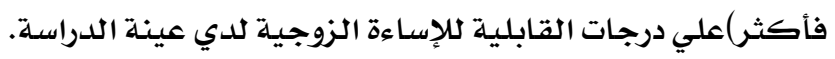

تم حساب المتوسطات الحسابية والانحرافات المعيارية لعينة الدراسـة الحالية طبقا لوجود

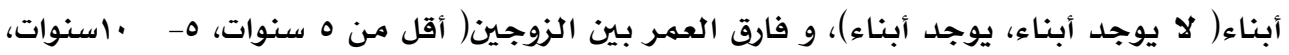

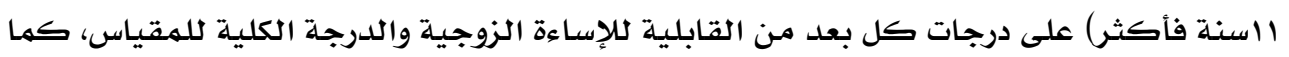

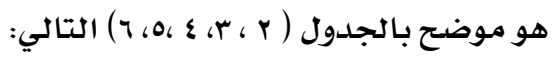

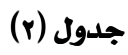

المتوسطات الحسابية والانحرافات المعيارية طبقا لوجود أبناء و فارق العمر بين

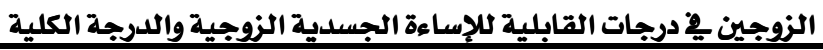

\begin{tabular}{|c|c|c|c|c|c|c|c|c|c|}
\hline \multicolumn{3}{|c|}{ الدرجة الكلية } & \multicolumn{3}{|c|}{ يوجد أبناء } & \multicolumn{3}{|c|}{ لا يوجد أبناء } & \multirow{2}{*}{ فارق العمر بين الزوجين وجود أبناء } \\
\hline$\varepsilon$ & ? & $\dot{j}$ & $\varepsilon$ & 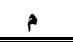 & j & $\varepsilon$ & ? & $\dot{j}$ & \\
\hline$\xi, 0$ & $r \cdot, 7 r$ & Ar & $\xi$, Vo & $r \cdot, \Sigma q$ & at & $r, 0$. & $\mathrm{r}, \cdot 0$ & 19 & أقل من هسنوات \\
\hline$\eta, r v$ & $r \cdot, 07$ & $n$ & 7,11 & $\mathrm{HI}, \$ 9$ & 70 & $0,0 \mathrm{Y}$ & $r \cdot 0$. & 9 & 0_•ا سنوات \\
\hline r,rr & $r \varepsilon, 7 r$ & $\Delta 9$ & $r, r i$ & $r o, \cdot \cdot$ & $\leqslant 9$ & $1, r 9$ & $r r, \Lambda^{*}$ & 1. & السنه فأكثر \\
\hline v, vo & Pr, 10 & rir & $\mathbf{V}, \wedge \mathrm{N}$ & rA, O\& & irv & $7, \xi Y$ & $r \xi, r$ & ro & الدرجة الكلية \\
\hline
\end{tabular}




$$
\text { جدول (r) }
$$

المتوسطات الحسابية والانحرافات المعيارية طبقا لوجود أبناء و فارق العمر بين

الزوجين على درجات القابلية للإساءة النفيسة الزوجية والدرجة الكلية

\begin{tabular}{|c|c|c|c|c|c|c|c|c|c|}
\hline \multicolumn{3}{|c|}{ الدرجة الكلية } & \multicolumn{3}{|c|}{ يوجد أبناء } & \multicolumn{3}{|c|}{ لا يوجد أبناء } & \multirow{2}{*}{ فارق العمر بين الزوجين وجود أبناء } \\
\hline$\varepsilon$ & ? & $\dot{j}$ & $\varepsilon$ & ? & j & $\varepsilon$ & 今 & j & \\
\hline$\xi,\{\wedge$ & $r \cdot, 1 \Lambda$ & Ar & $\varepsilon, 7 r$ & 19,97 & Tr & $\varepsilon, \bullet$ & $r \cdot, \wedge q$ & 19 & أقل من ه سنوات \\
\hline 7,80 & $r I, \cdot v$ & n & 0, Yo & rr,,$\varepsilon$ & 70 & $r, 7 r$ & $r \cdot, 0$. & 7 & 0 \\
\hline$r, r v$ & $r \xi, r V$ & $\Delta q$ & $r, \xi r$ & $r \xi, \xi r$ & $\leqslant 9$ & 1,97 & $r r, 0$. & 1. & ال سنة فأكثر \\
\hline $\mathbf{V}, \mathbf{\wedge}$ & rv, ro & rir & $\vee, \wedge 0$ & $\wedge, \xi$ & IVY & 7, Yo & $r \xi, \xi Y$ & ro & اللدرجة الكلية \\
\hline
\end{tabular}

جدول (६)

المتوسطات الحسابية والانحرافات المعيارية طبقا لوجود أبناء و فارق العمر بين الزوجين

على درجات القابلية للإساءة الجنسية الزوجية والدرجة الكلية

\begin{tabular}{|c|c|c|c|c|c|c|c|c|c|}
\hline \multicolumn{3}{|c|}{ الدرجة الكلية } & \multicolumn{3}{|c|}{ يوجد أبناء } & \multicolumn{3}{|c|}{ لا يوجد أبناء } & \multirow{2}{*}{ فارق العمر بين الزوجين وجود أبناء } \\
\hline$\varepsilon$ & 今 & $\dot{j}$ & $\varepsilon$ & 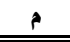 & j & $\varepsilon$ & 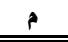 & $\dot{j}$ & \\
\hline$\$, 17$ & $r \cdot, r q$ & Ar & $\xi, Y\urcorner$ & $r \cdot r v$ & $9 r$ & r,ar & 19,19 & 19 & أقل من ه سنوات \\
\hline$v, \cdot r$ & $r \cdot, 97$ & n & 0,11 & $r r, r \cdot$ & 70 & $\xi, 7 \wedge$ & iv, o. & 7 & 0 \\
\hline$r, r q$ & $r \xi, r r$ & $\Delta 9$ & r,rr & $r \xi, r v$ & $\leqslant 9$ & $1, \wedge \varepsilon$ & rr, o. & 1. & II سنة فأكثر \\
\hline$\checkmark, \wedge \varepsilon$ & $r Y, r r$ & rir & $v, 70$ & $r \Lambda, O \Lambda$ & IVY & $v, \varepsilon r$ & $r r, r v$ & ro & اللدرجة الكلية \\
\hline
\end{tabular}

$$
\text { جدول (0) }
$$

المتوسطات الحسابية والانحرافات المعيارية طبقا لوجود أبناء و فارق العمر بين الزوجين

\begin{tabular}{|c|c|c|c|c|c|c|c|c|c|}
\hline \multicolumn{3}{|c|}{ اللدرجة الكلية } & \multicolumn{3}{|c|}{ يوجد أبناء } & \multicolumn{3}{|c|}{ لا يوجد أبناء } & \multirow{2}{*}{ فارق العمر بين الزوجينز } \\
\hline$\varepsilon$ & ? & j & $\varepsilon$ & 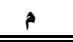 & $\dot{j}$ & $\varepsilon$ & $\hat{2}$ & $\dot{j}$ & \\
\hline 8,77 & $r 1, \cdot 7$ & Ar & $\varepsilon, \eta v$ & $r, r \cdot$ & Tr & $\varepsilon, 7 r$ & $r \cdot, r q$ & 19 & أقل من ه سنوات \\
\hline$\checkmark, 17$ & $r \cdot, 7 \Lambda$ & $n$ & 0,9 . & $r 1,90$ & 90 & $\xi, 0 \Lambda$ & 17, Ar & 1 & 0 \\
\hline r, ro & r\&, rq & $\Delta 9$ & $r, \$ 1$ & $r \varepsilon, \varepsilon r$ & $\varepsilon 9$ & $r, 11$ & $r \varepsilon, \cdot \cdot$ & 1. & ا سنة فأكثر \\
\hline$v, v$. & $r v, 9 \Lambda$ & rir & $v, r q$ & $r \Lambda, \wedge 0$ & irv & $\vee, \wedge \eta$ & rr,, . & ro & اللدرجة الكلية \\
\hline
\end{tabular}

على درجات القابلية دلإساءة الاقتصادية الزوجية والدرجة الكلية 


$$
\text { جدول (7) }
$$

المتوسطات الحسابية والانحرافات المعيارية طبقا لوجود أبناء و فارق العمر

بين الزوجين على الدرجة الكلية للقابلية للإساءة الزوجية

\begin{tabular}{|c|c|c|c|c|c|c|c|c|c|}
\hline \multicolumn{3}{|c|}{ اللدرجة الكلية } & \multicolumn{3}{|c|}{ يوجد أبناء } & \multicolumn{3}{|c|}{ لا يوجد أبناء } & 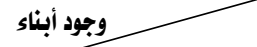 \\
\hline$\varepsilon$ & 今 & $\dot{j}$ & $\varepsilon$ & ? & $\dot{j}$ & $\varepsilon$ & $\hat{H}$ & $\dot{j}$ & فارق العمربين الزوجيي \\
\hline Ir,Y & $\Delta r, I r$ & Ar & $\mathrm{Ir}, \mathrm{A \Lambda}$ & $A r, I r$ & Tr & $11, r$. & Ar,l. & 19 & أقل من ه سنوات \\
\hline ro,Ar & IrT,YY & n & Y1,97 & Irv, & 70 & 17,00 & Vo,rr & 7 & 0--•اسنوات \\
\hline $0,0 \mathrm{~V}$ & $\mid r v, \varepsilon v$ & $\Delta 9$ & $0,7 r$ & IrA,r & $\Sigma 9$ & $r, 70$ & Irr, & 1. & ال سنة فأكثر \\
\hline r৭,\$१ & $111, r+$ & rir & $r q, 11$ & $11 \varepsilon, r$ & IVY & rq,\$l & $90, \mathrm{VI}$ & ro & اللدرجة الكلية \\
\hline
\end{tabular}

• كما تم استخدام تحليل التباين ثنائى الاتجاه (YXYY)، وكذلك حساب حجم التأثير من خلال

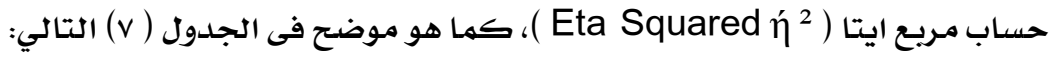

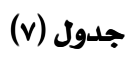

تحليل التباين ثنائى الاتجاه (Yxp) وحجم التأثير لوجود أبناء و فارق العمر بين

\begin{tabular}{|c|c|c|c|c|c|c|c|c|}
\hline التأثير| & مربع معامل & مستوى الدلالة & قيمة & متوسط & الحرية & مجموع & مصدر التباين & الإساءة \\
\hline متوسط & $\bullet, \bullet \wedge 1$ & $\cdot, \cdot \cdot 1$ & 19,979 & $\xi r \cdot, 1$ r & 1 & $\left\{r \cdot, 1 r_{0}\right.$ & وجود أبناء (أ) & \multirow{4}{*}{ جسدية } \\
\hline كبيرجدا & •,\$01 & $\cdot, \cdot \cdot 1$ & $A \varepsilon, 7 Y r$ & IArq, raA & $r$ & ryor, va & فارق العمربين الزوجين (ب) & \\
\hline \multirow[t]{2}{*}{ 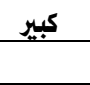 } & $\cdot, 1 \cdot r$ & $\cdot, \cdot \bullet 1$ & $r, r q r$ & rฯy,All & $r$ & orr, Trr & التفاعل(أ × ب) & \\
\hline & & & & MI,OAY & $r \cdot \eta$ & $\llbracket \llbracket \varepsilon 7, \bullet \xi$ & الخطأ الخأ & \\
\hline متوسط & $\bullet,+\wedge \bullet$ & $\cdot, \cdot \bullet 1$ & IV, 9r & roq, o. & 1 & roq, o. & وجود أبناء ( أ) & \multirow{4}{*}{ نفسية } \\
\hline كبيرجدا & $\cdot,\{1 \uparrow$ & $\cdot, \cdot \bullet 1$ & $9 Y, r r$ & $19 \leqslant 7,01$ & $r$ & rA94,17 & فارق العمر بين الزوجين (ب) & \\
\hline \multirow[t]{2}{*}{ كبير } & • Ir\& & $\cdot, \cdot \cdot 1$ & $10, \mathrm{AV}$ & rIV, Os & r & $970, \cdot 9$ & التفاعل( أ × ب) & \\
\hline & & & & $r \cdot, \cdot \cdot$ & $r \cdot \eta$ & $\$ 1 r \cdot, 0 \Lambda$ & 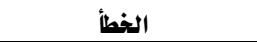 & \\
\hline 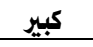 & $\cdot, 1 \leqslant 9$ & $\cdot, \cdot \cdot 1$ & $r q, \cdot v$ & 79r, ז६ & 1 & 794, זะ & وجود أبناء (أ) & \multirow{4}{*}{ جنسية } \\
\hline كبيرجدا & $\cdot, 0.0$ & $\cdot, \cdot \bullet 1$ & $1 . \&, 9 Y$ & $r \cdot 1 Y, 99$ & $r$ & $\varepsilon \cdot \% 0,91$ & فارق العمر بين الزوجين (ب) & \\
\hline \multirow[t]{2}{*}{ 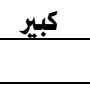 } & $\cdot$ •IAT & $\cdot, \cdot \cdot 1$ & $\mathrm{rr}, \mathrm{A \Lambda}$ & $\{r q, q r$ & $r$ & $\wedge \vee \neg, \wedge 0$ & التفاعل( أ × ب) & \\
\hline & & & & $19, r r$ & $r \cdot 7$ & $r 97 \cdot, 11$ & الخطأ & \\
\hline كبير & $\cdot, 180$ & $\cdot, \cdot \bullet 1$ & $r \xi, \Lambda \cdot$ & $\xi v, r$. & 1 & skl, v. & وجود أبناء( أ) & \multirow{4}{*}{ إقتصادية } \\
\hline كبيرجدا & $\cdot, \Sigma T \mathrm{~V}$ & $\cdot, \cdot \cdot 1$ & $9 \cdot, \mathrm{rA}$ & $19 Y \varepsilon, 11$ & $r$ & $r A \leqslant \Lambda, Y I$ & فارق العمر بين الزوجين (ب) & \\
\hline \multirow[t]{2}{*}{ كبير } & $\cdot|\mathrm{r}|$ & $\bullet, \cdot \cdot 1$ & $M, r$ & ร०६, IV & $r$ & $9 \cdot 1, r 0$ & التقاعل( أ × ب) & \\
\hline & & & & $M, r I \varepsilon$ & $r+7$ & \$rq., 70 & الخطأ & \\
\hline 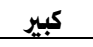 & $\cdot, 100$ & $\cdot, \cdot \bullet 1$ & $r v, v$. & $\wedge 79 \Lambda, 89$ & 1 & 1991,89 & وجود أبناء ( أ) & \multirow[t]{3}{*}{ المجموع } \\
\hline كبيرجدا & $\cdot, 07 \xi$ & $\cdot, \cdot \bullet 1$ & IrT, rA & r.vor,ar & $r$ & $910 \cdot 0,10$ & فارق العمر بين الزوجين (ب) & \\
\hline 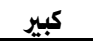 & $\cdot, 190$ & $\bullet, \cdot \bullet 1$ & $Y \xi, q \xi$ & ovos, or & $r$ & $110.9,18$ & التفاعل( أ × ب) & \\
\hline
\end{tabular}

الزوجين على درجات القابلية دلإساءة الزوجية

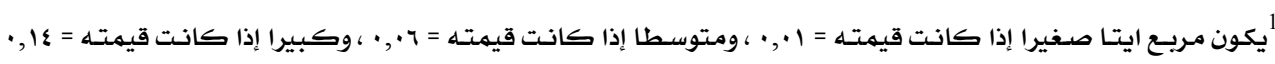

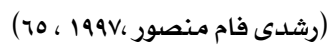




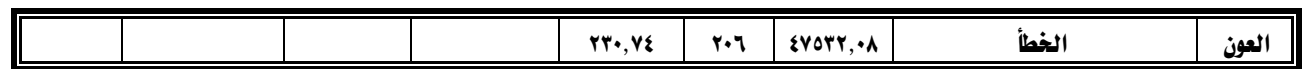

$$
\text { يتضح من جدول (r، r، ع، 0، 7)، و جدول (v) ما يلى : }
$$

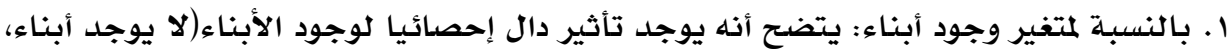

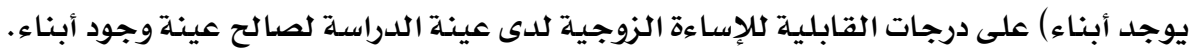

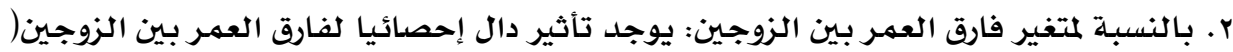

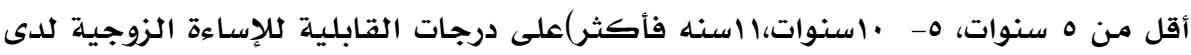

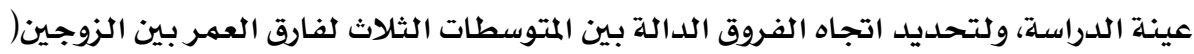

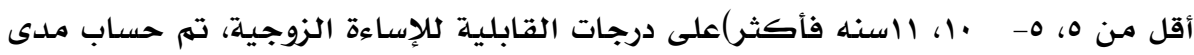

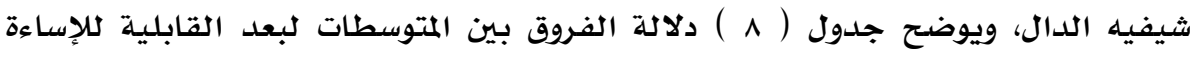

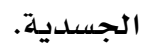

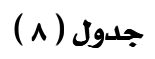

دلالة الفروق بين المتوسطات لبعد القابلية للإساءة الجسدية

\begin{tabular}{|c|c|c|c|}
\hline ا سنة فأكثر & 0--•اسنوات & أقل من ه سنوات & فارق العمر بين الزوجين \\
\hline$r \xi, 7 r$ & $r \cdot, 07$ & $r \cdot, 7 r$ & أقل منهسنوات(r T • •r) \\
\hline$+1 \varepsilon,+1$ & $\frac{*}{x} 9,9 \varepsilon$ & - & 0 ـ• اسنوات (r,07) \\
\hline$\left.\frac{*}{x} \varepsilon, \cdot\right\urcorner$ & - & - & ال سنه فأكثر(rך, §ץ) \\
\hline
\end{tabular}

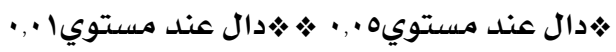

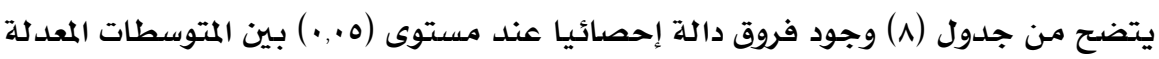

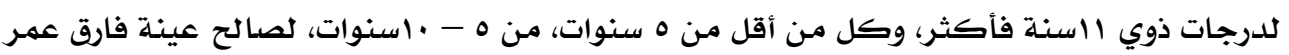

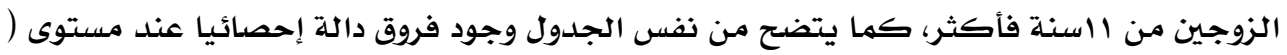

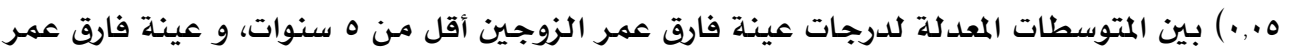

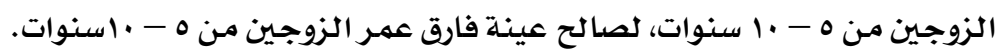
ويوضح جلدول ( ه ) دلالة الفروق بين المتوسطات لبعد القابلية للإساءة النفسية .

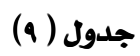

\begin{tabular}{|c|c|c|c|}
\hline ا 11 سنة فأكثر & 0 - •اسنوات & أقل من ه سنوات & فارق العمر بين الزوجين \\
\hline T\&, YV & $r I, \bullet V$ & $r \cdot, 1 \mathrm{~A}$ & 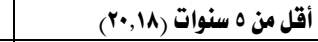 \\
\hline $\pm 1 E, \cdot 9$ & $\pm 1 \cdot, \wedge \Lambda$ & - & 0- •ا سنوات (v•, rاr) \\
\hline $\pm r, r$. & - & - & السنه فأكثر (r\&, rv) \\
\hline \multicolumn{3}{|c|}{ *** عند مستويا •, . } & *دال عند مستويه ., . \\
\hline
\end{tabular}

دلالة الفروق بين المتوسطات لبعد القابلية كلإساءة النفسية 
يتضح من جدول(ه)وجود فروق دالة إحصائيا عند مستوى(ه.,•) بين المتوسطات المعدلة

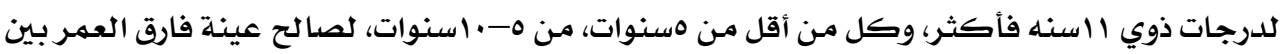

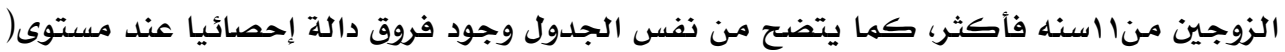

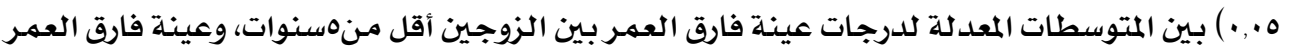

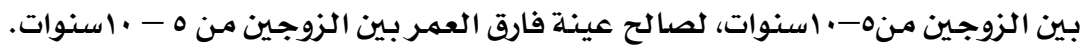
ويوضح جدول (ـ ) دلالة الفروق بين المتوسطات لبعد القابلية للإساءة الجنسية.

$$
\text { جدول (1.) (1) }
$$

دلانة الفروق بين المتوسطات لبعد القابلية كلإساءة الجنسية

\begin{tabular}{|c|c|c|c|}
\hline ا سنة فأكثر & 0--•اسنوات & أقل من ه سنوات & فارق العمر بين الزوجين \\
\hline rE, rr & $r \cdot, 97$ & $r \cdot, r q$ & أقل من ه سنوات (Y.r. \\
\hline$\frac{*}{14,97}$ & $\pm 1 \cdot, y$ & - & 0- • اسنوات (97, , \\
\hline$\frac{*}{x} r, r q$ & - & - & II سنه فأكثر (Yr,Yr) \\
\hline
\end{tabular}

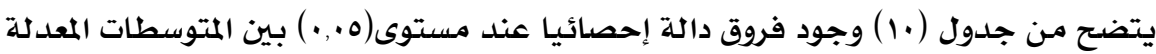

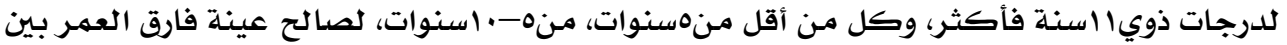

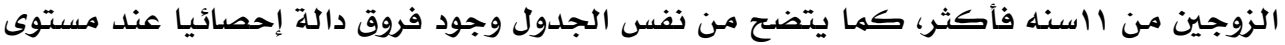

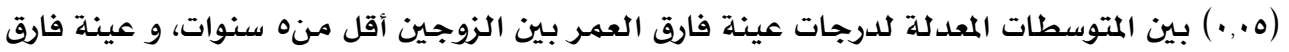

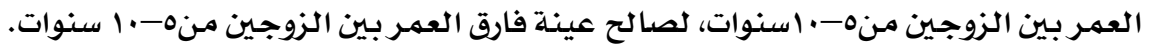
ويوضح جدول (11) دلالة الفروق بين المتوسطات لبعد القابلية للإساءة الاقتصادية .

جدول (ii)

دلالدة الفروق بين المتوسطات لبعد القابلية كلإساءة الاقتصادية

\begin{tabular}{|c|c|c|c|}
\hline ا Iانة فأكثر & 0 & أقل من ه سنوات & فارق العمر بين الزوجين \\
\hline rE, ro & $r \cdot$, Tr & $r 1, \cdot 7$ & أقل من ه سنوات (Y) (Y) \\
\hline$\frac{*}{x} \mid r, r$. & $\underset{x}{*} 9,7 r$ & - & 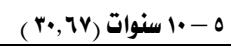 \\
\hline $\pm r, 7 \Lambda$ & - & - & II سنه فأكثر (Y), Y\%) \\
\hline
\end{tabular}

يتضح من جدول(11) وجود فروق دالة إحصائيا عند مستوى(ه)., •) بين المتوسطات المعدلة

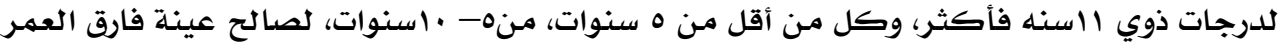

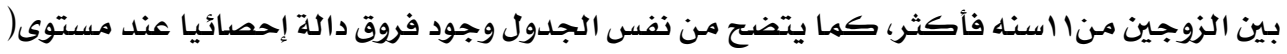


ه., ) بين المتوسطات المعدلة لدرجات عينة فارق العمر بين الزوجين أقل من هسنوات، وعينة فارق

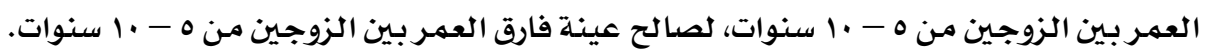
ويوضح جدول (r ا ) دلالة الفروق بين المتوسطات لمجموع القابلية للإساءة الزوجية.

جدول (ir)

دلالة الفروق بين المتوسطات لمجموع القابلية للإساءة الزوجية

\begin{tabular}{|c|c|c|c|}
\hline II 11 & 0 & أقل من ه سنوات & مجموع القابلية للإساءة الزوجية \\
\hline $\mid T V, \xi V$ & IrT, rV & $\Delta r, I r$ & أقل من ه سنوات (r, Ir \\
\hline \pm 00, ro & $\pm \$ 1,10$ & - & 0 \\
\hline$\dot{*} \mid \varepsilon, Y$ & - & - & II سنه فأكثر(ITV,ZV \\
\hline
\end{tabular}

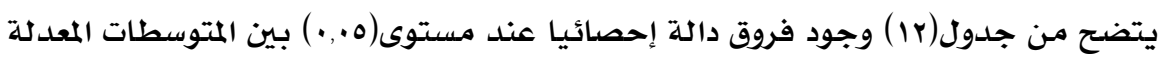

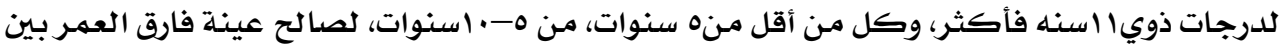

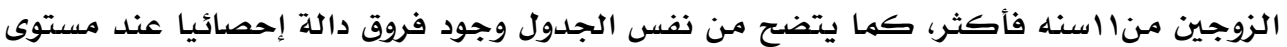

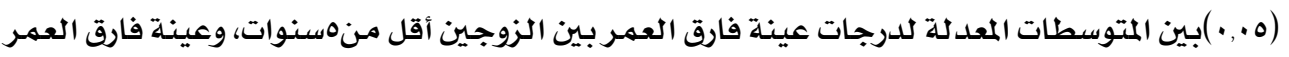

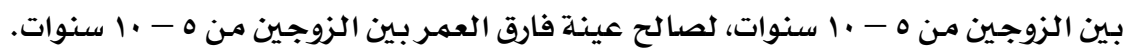

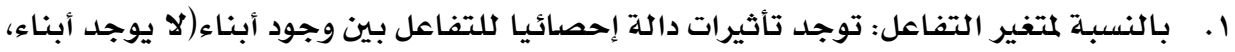

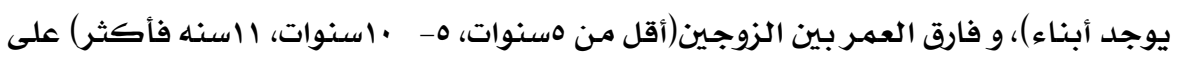

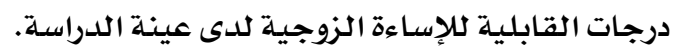

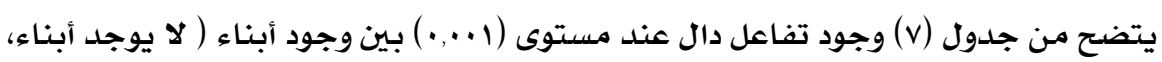

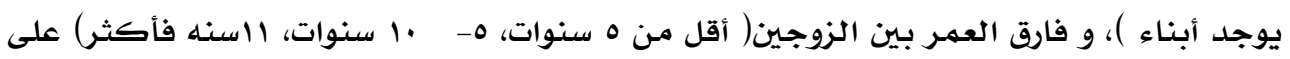

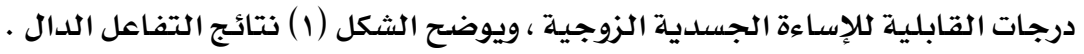

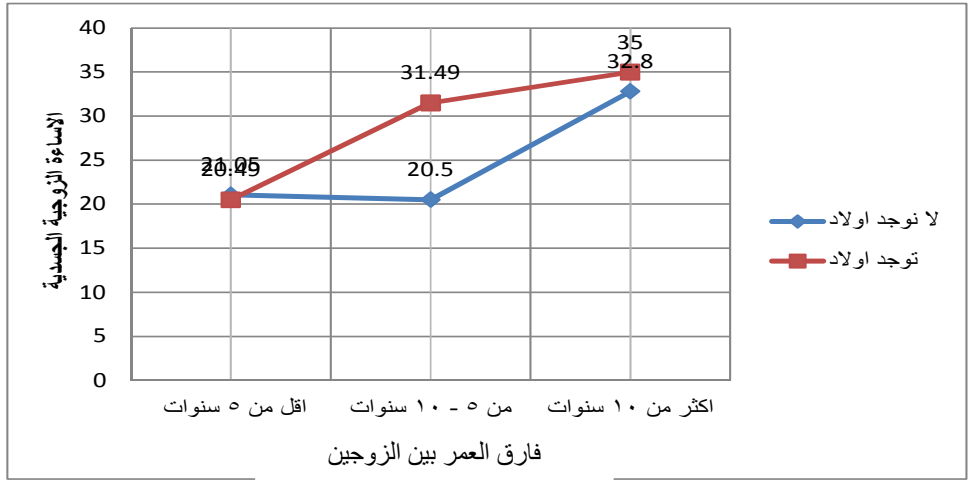

شكل ( 1 ) التفاعل بين وجود أبناء و فارق العمر بين الزوجين

على درجات القابلية للإساءة الجسدية الزوجية أبناءو فارقائ 


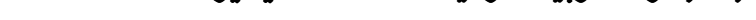

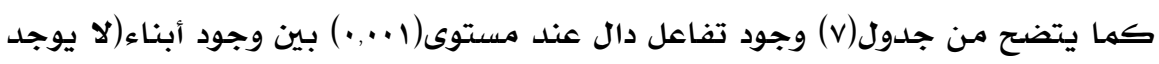

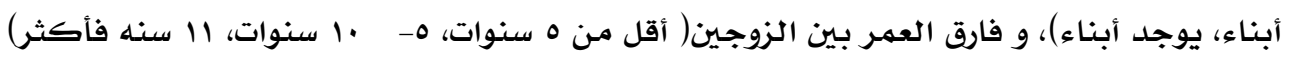

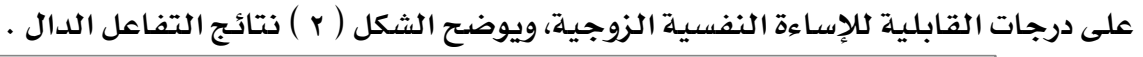

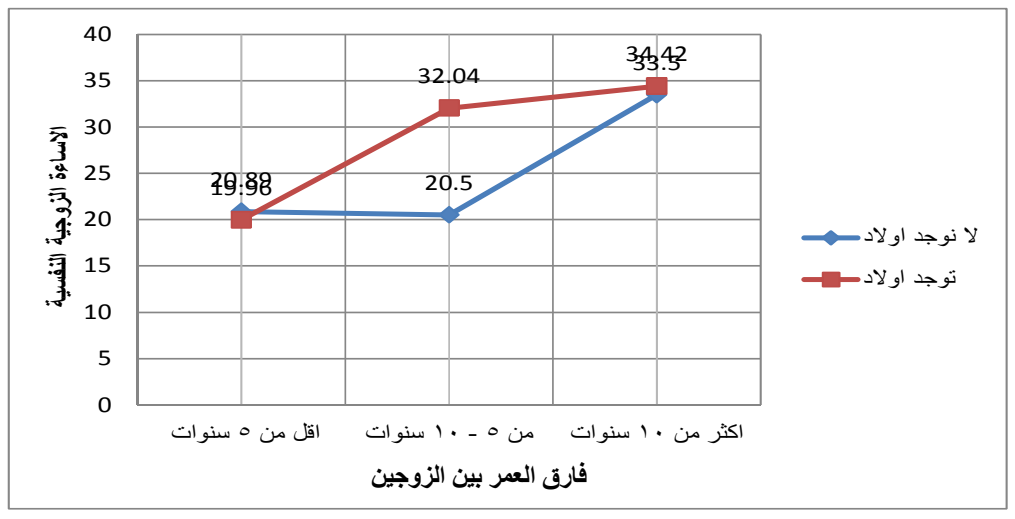

شكل (r) التفاعل بين وجود أبناء و فارق العمر بين الزوجين

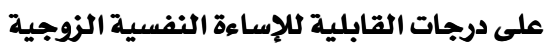

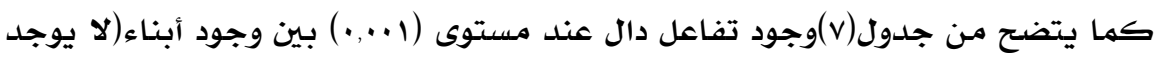

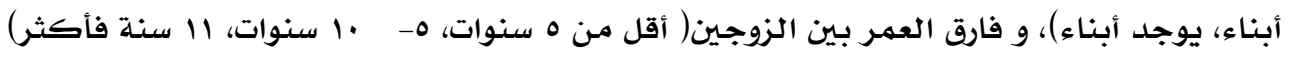

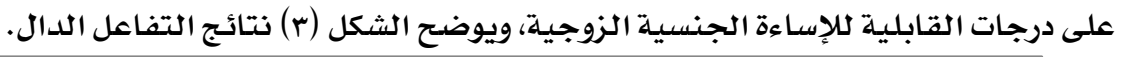

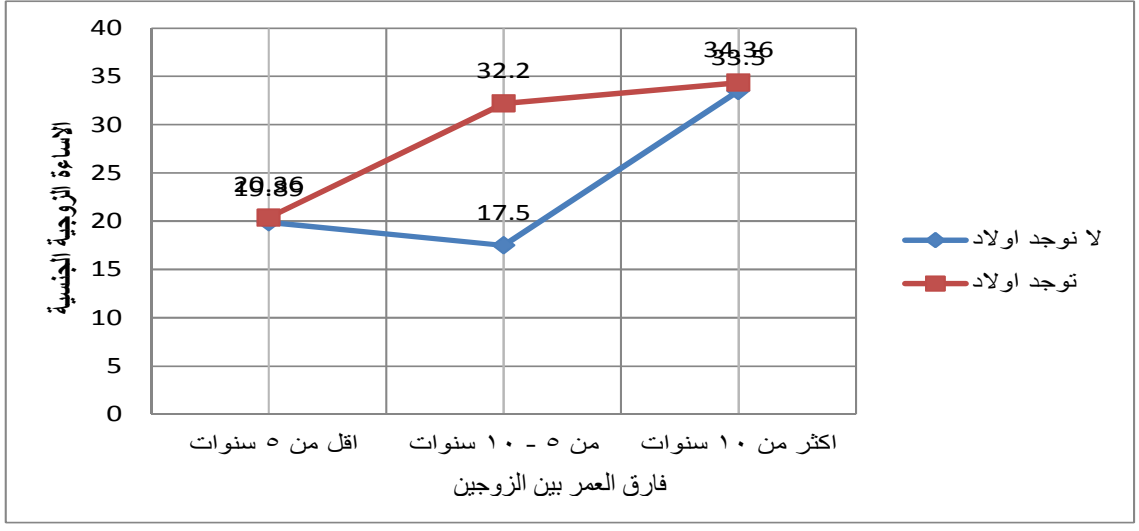

\section{شكل (r) التفاعل بين وجود أبناء و فارق العمر بين الزوجين}

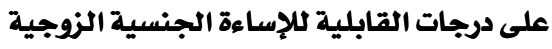

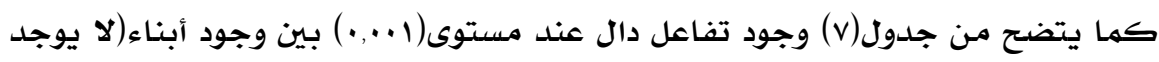

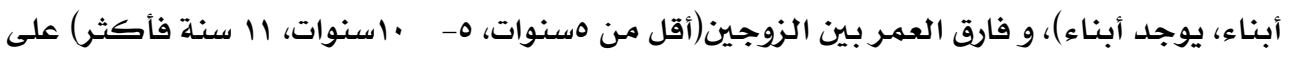

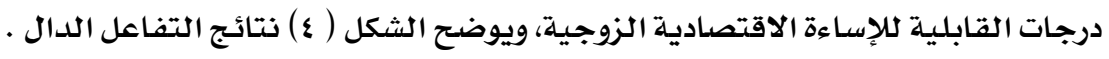




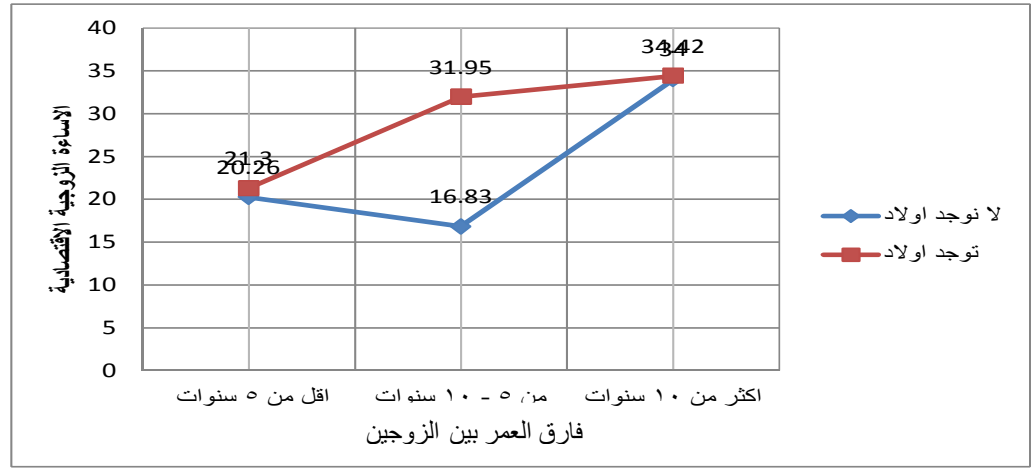

شكل (ع ) التفاعل بين وجود أبناء و فارق العمر بين الزوجين

على درجات القابلية للإساءة الاقتصادية الزوجية وائية

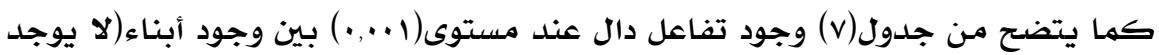

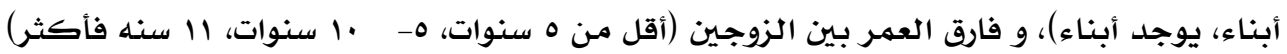

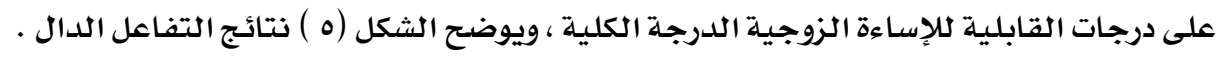

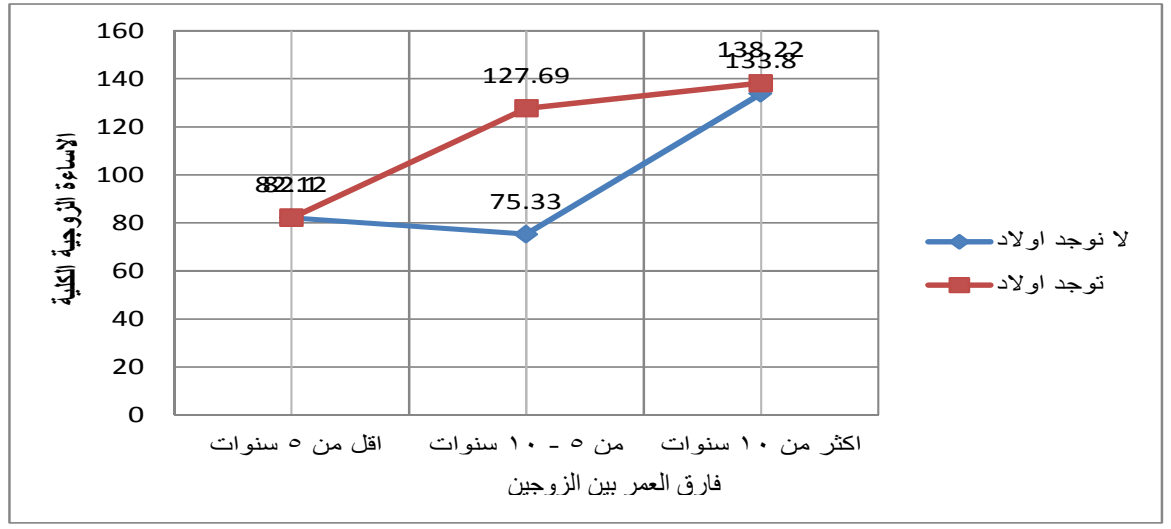

شكل(ه) التفاعل بين وجود أبناء و فارق العمر بين الزوجين

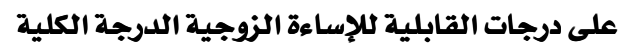

وهذه النتائج تشير إلي عدم تحقق صحة الفرض الثاني والثالث والرابع الصفرية وقبول

الفروض البديلة والذي تنص على أنه:

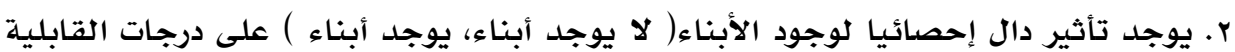

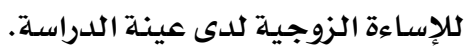

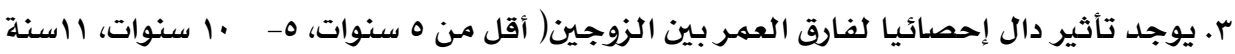

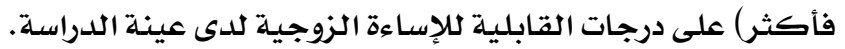




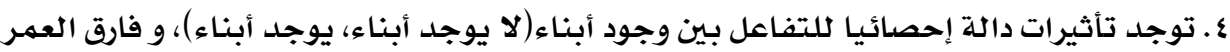

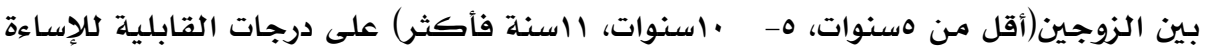
الزوجية لدى عينة الدراسلة.

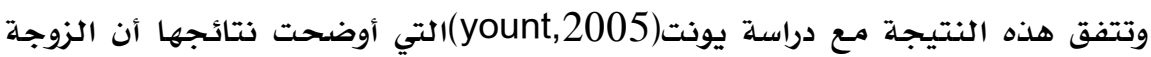

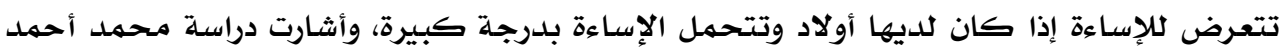

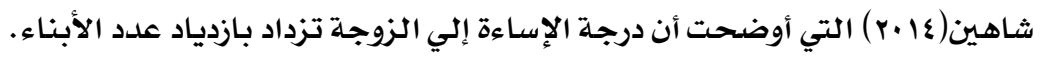

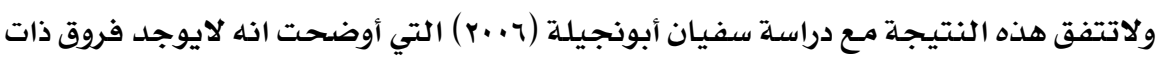

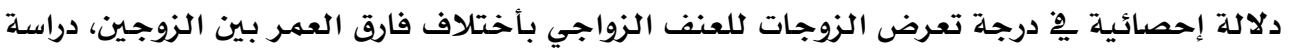

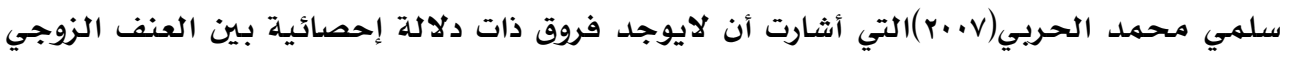

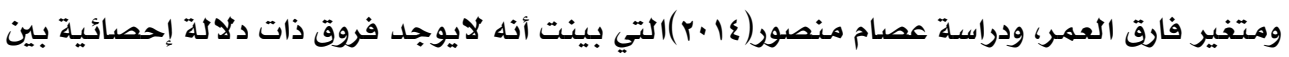

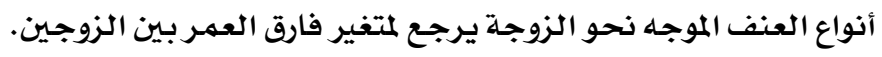

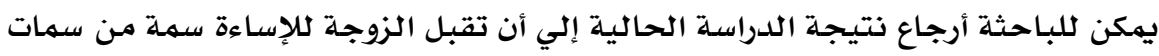

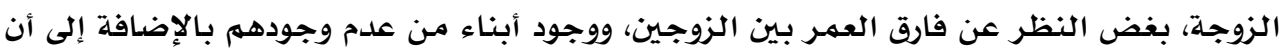

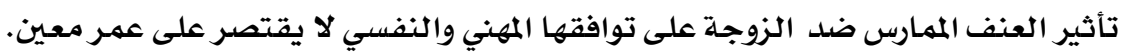

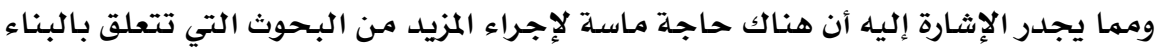

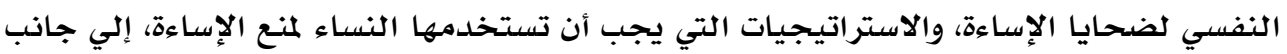

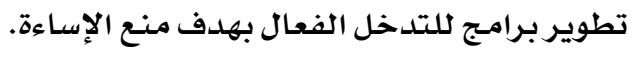

ا. إجراء المزيد من الدراسات الاجتماعية والنفسية التي تهدف لتحديد الأسباب الكامنة وراء

$$
\text { القابلية للإساءة الزوجية. المزية. }
$$

r. تكثيف البر امج التي تهدف إلي توعية الزوجة بحقوقها، وتزوةدودها بالاستراتيجيات التي تكفل تسوية الخلافات بطرق سوية بعيدة عن الإساءة. r. ضرورة قيام المؤسسات النسوية والحقوقية بتقديم الخدمات الإرشادية الوقائية والعلاجية الإنية

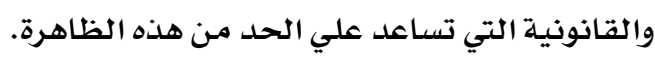

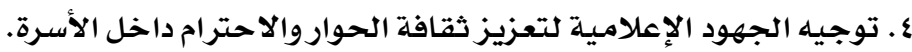

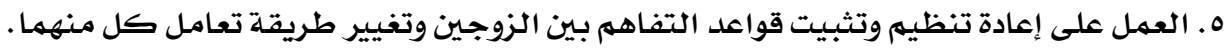

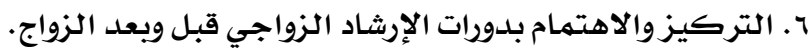

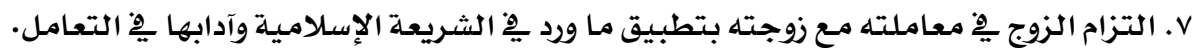
^. التركيز على توعية الزوجة المسلمة بحقوقها الشرعية على زوجها وواجباته نحوها قبل التراتل الزواج. 9. تفعيل الإرشاد الأسري يِّ المؤسسات الاجتماعية والتعليمية ليتناول مشكلات الأسرة وكيفية

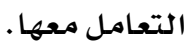


ا ـ إجراء الدراسات التي تهتهم بالتعرف علي ديناميات شخصية الزوج المسئ إلي زوجته والزوجة المتقبلة للإسـاءة.

r. إجراء دراسة تتعرف علي أسباب تقبل الزوجة للإِساءة إلهاءة ووضع البرامج العلاجية المناسبة للقضاء أو التقليل من هذه الأسباب.

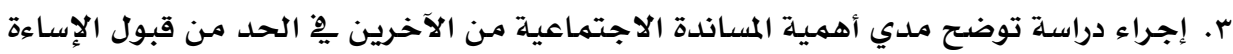

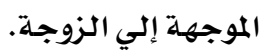

ـ. إعداد برامـج إرثادية أسرية يفّة مجال لتحسين التوافق للزوجات المساء اليهن.

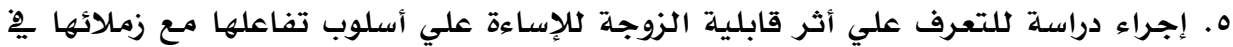

• إبراهيم شوقي عبد المجيد (1999). دراسة مقارنة للتوافق المهني بين العاملين الدارسين وغير الدارسين

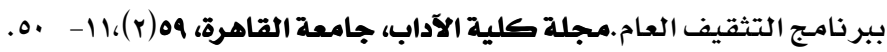

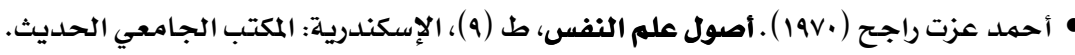

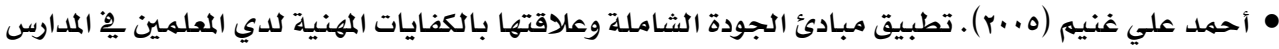

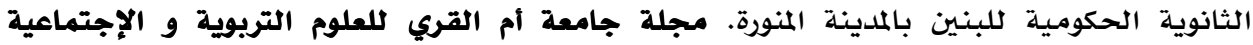

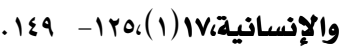

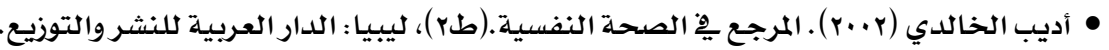

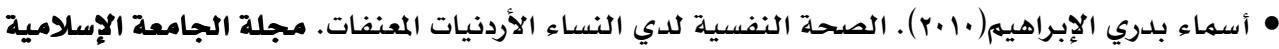
للبحوث الإنسانية_ شئون البحث العلمي والدراسات العليا بالجامعة الإسلامية، غزية، فلسطين، orra - rrq،(r)M

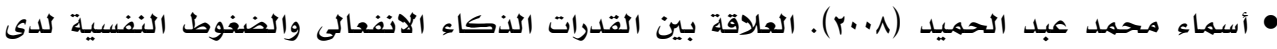

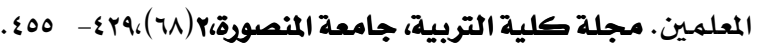

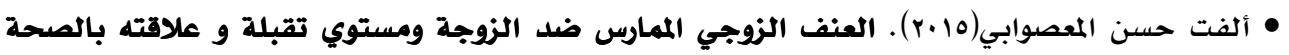

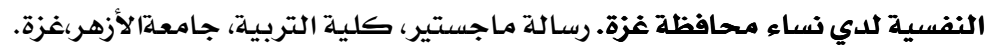

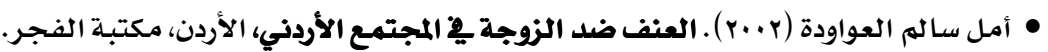

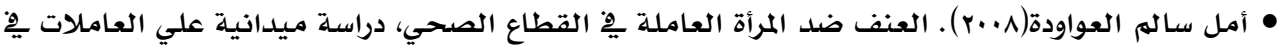

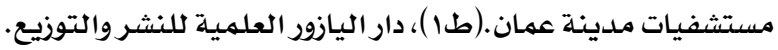

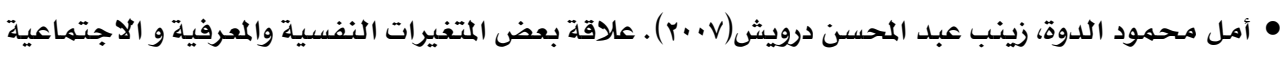

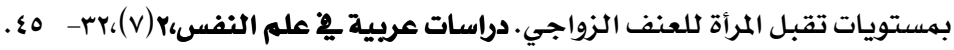

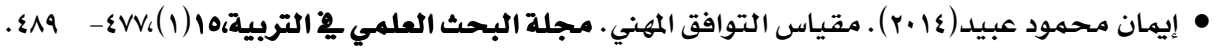




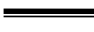
مجلة بحوث التربية النوعية - علدد r. 19 - ميناير

• جمال عبد الحميد جادو(10 +r). إساءة معاملة الزوجة ِِ جنوب صعيد مصر وعلاقتها ببعض المتغيرات.

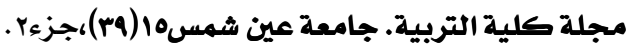
• حامد عبد السلام زهران (1910) ـ الصححة النفسية والعلاج النفسي. عالهم الكتب، القاهرة. • حمدي علي الفرماوي، رضا عبدالله ( • +r) . الضفوط النفسية فِ مجال العمل والحياة، مواجهات نفسية فِ سبيل التنمية البشرية. عمان : دار صفاء للطباعة والنشر والتوزيـع. • خولة أحمد يحيي( (... ) . الاضطرابات السلوكية والانفعالية. عمان: دار الفكر للطباعة والتوزيع.

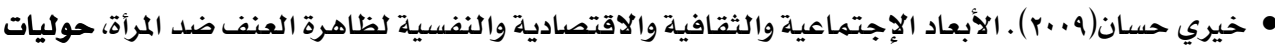
آداب عين شمس، RV،

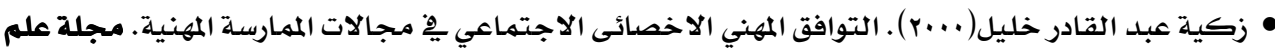
النفس الهيئة العامة للكتاب.

• سحر يوسف الشرع (YV) (r). العنف الموجـه ضد الزوجة يِّ الأسرة الأردنية واشكاله ومـرتكزاته الجندرية.

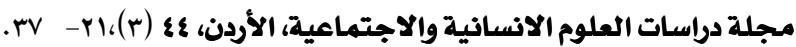
• سعد رياض البيومى (1991) ـ. قدرة المؤسسة الإنتاجية علي إثباع الحاجات المتدرجة وعلاقتها بالتوافق العام والمهنى. رسالة ماجستير، كلية الآداب، جامعة طنطا.

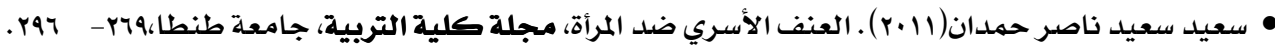

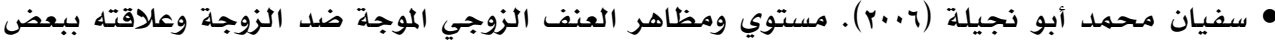

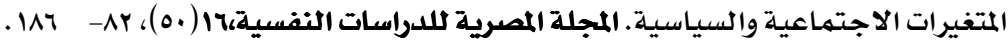
• سميلة عمارة(و...). صـراع الأدوار وتأثيره علي التوافق المهني للطلاب العاملين بالمركز الجامعي. مجلة

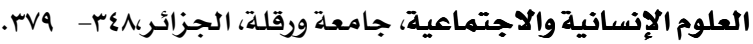

• طارق كمال(v . . . ) . علم النفس المهني والصناعي. مؤسسة شباب جامعة الأسكندرية.

• طريف شوقي فرج(r.?). العنف ِِ الأسرة المصرية، التقرير الثاني، دراسة نفسية استكشافية، القاهرة، المركز القومي للبحوث الاجتماعية والجنائية.

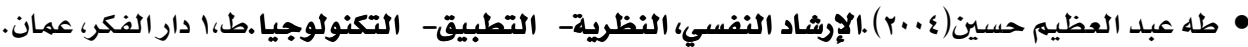
• طه عبد العظيم حسين(ج . . ) . استراتيجية إدارة الضغوط التربوية والنفسية. دار الفكر، عمان.

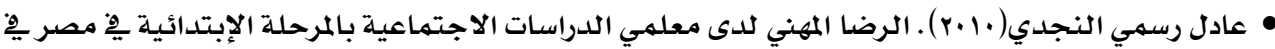
ضوء تطبيق إستراتيجيتي التقويه الشامل والتعلم النشط. مجلة العلوم التربوية والنفسية،||(r)،وسץrTY • عباس محمود عوض (1997) .الموجز هِّ الصحة النفسية. القاهرة: دار المعارف.

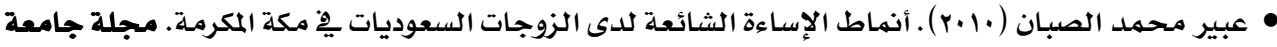

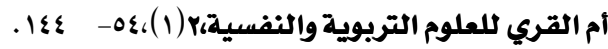

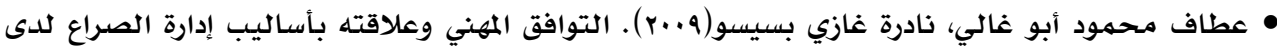

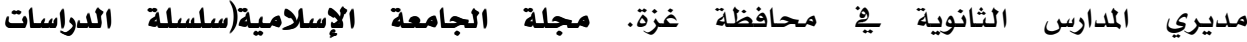
. الإنسانية) 
• عمر مصطفي النعاس (r •r). أساليب مواجهة الضغوط ويعض المتغيرات النفسية و الديموجرافية المنبئة

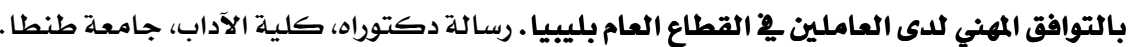

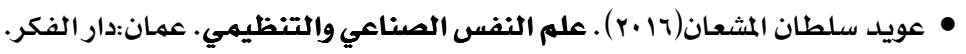

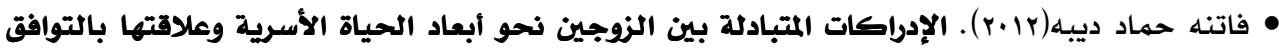
الزواجي. رسالة ماجستير، جامعة الأزهر. فلسطين.

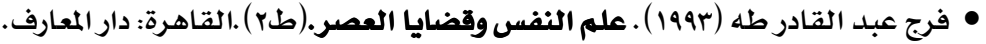

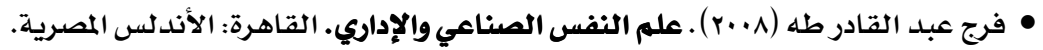

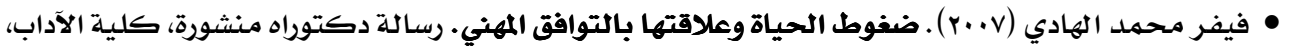
جامعة عين شمس. • ماهر عبد الرزاق سكران (11 +r). التوافق المهني ِِّ علاقته بالمسانده الإجتماعية. مجلة الخدمة الاجتماعية.

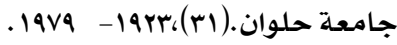

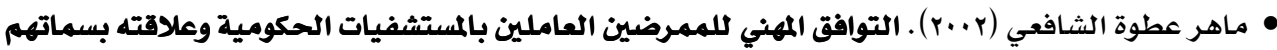

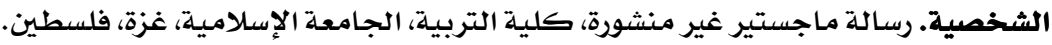

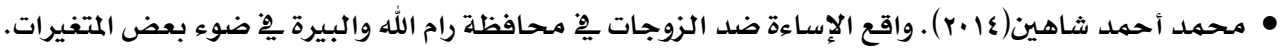

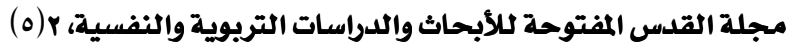

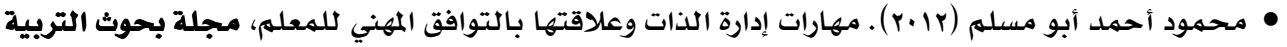

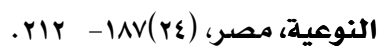

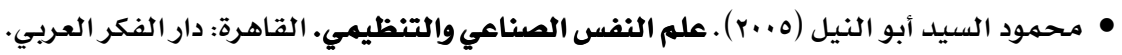

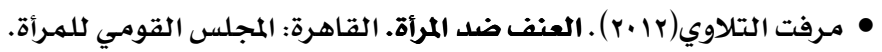

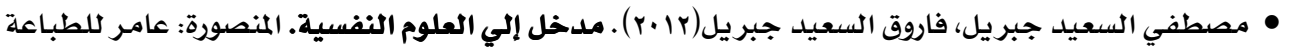
والنشر. • منال محمد عباس(11) مالنشر). العنف الأسري رؤية سوسيولوجية، الإسكندرية: دار المعرفة الجامعية للنشر.

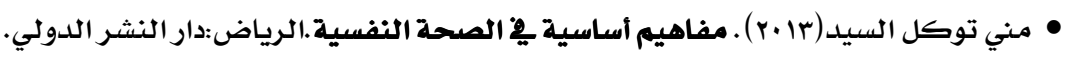

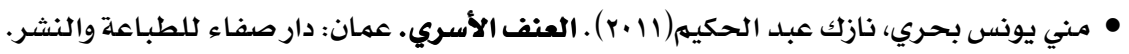

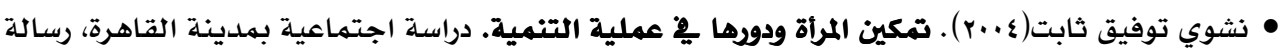

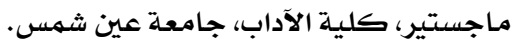

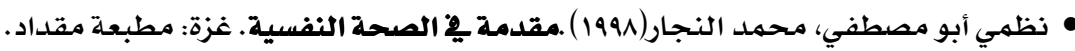

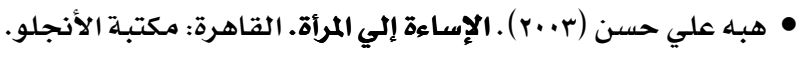

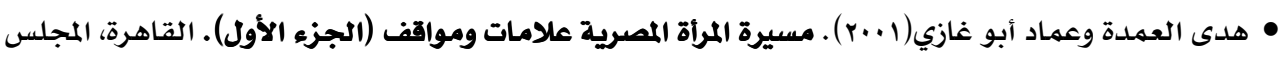
القومي للمرأة.

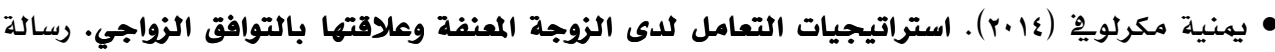
ماجستير، كلية العلوم الاجتماعية، جامعة وهران. 
- Banyard, V.,Potter,S.,\& Turner, H.(2011). The impact of interpersonal violence in adulthood on women's job satisfaction and productivity ; The mediating roles of mental and physical health. Psychology of violence,1(1),16.

- Macgregor,J.C.,Macquarrie,B.J., \& Wathen,C.N.(2015). The Impact of Domestic Violence in the Workplace. Journal of Occupational and Environmental Medicine, 57(7). . Reeves, C. A.,\& O'Leary_Kelly, A.(2012). Study of the effects of intimate partner violence on the workplace. USA: BiblioGov.

- Showalter, K. (2016). Women`s employment and domestic violence; a review of the literature. Aggression and violent behavior, 31,37-47.

- Yount, K. (2005). Resources Family organization and domesh's violence against married women in Mima- Egypt, Journal of Marriage and Family,67(3) 579-596.

- Yragui, N. L.(2008). Intimate Partner violence, supervisor support and work outcomes for low-wage workers(Doctoral dissertation, Portland State University. Systems Science Ph. D. program)

- https://www.aph.gov.au/parliamentary- Busi/

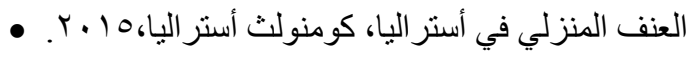


Abstract:

The current research aimed to shed light on the susceptibility of marital abuse and its relationship with vocational adjustment among primary school female teachers. The study was conducted on a sample of primary school female teachers in Kafr El-Sheikh Governorate. The study evolved from the following question: What is the relationship between the susceptibility of marital abuse and the vocational adjustment among primary school female teachers? in the light of two variables: the presence of children(with children, without children), and the difference of age between the couples (less than 5 years, 5-10 years, 11 years and over). The study sample reached 212 primary school female teachers and relied on the relational descriptive approach. The study tools were the measure of susceptibility to marital abuse(prepared by the researcher), and the measure of vocational adjustment (prepared by the researcher). The study came to the following conclusions: There is a statistically significant relationship between the susceptibility of marital abuse and the vocational adjustment of primary stage female teachers, There is a statistically significant effect on the susceptibility of marital abuse for the presence of children (with children - without children) on the degrees of susceptibility of marital abuse of primary school female teachers in favor of the presence of children, There is a statistically significant effect of the age difference between couples (less than 5 years, 5-10 years, 11 years and over) on the degrees of susceptibility of marital abuse of the female teachers of the primary stage in favor of 5-10 years of age difference, There was a statistically significant effect of interaction between the presence of children (with children, without children) and the age difference between couples (less than 5 years, 5-10 years, 11 years and over) on the degrees of susceptibility of marital abuse of primary school female teachers. 